\title{
Identifying factors that influenced wellbeing and learning effectiveness during the sudden transition into eLearning due to the COVID-19 lockdown
}

\author{
Alessandro Naddeo*, Rosaria Califano and Iolanda Fiorillo \\ Department of Industrial Engineering, University of Salerno, Via Giovanni Paolo II, 132, Fisciano, \\ Salerno, Italy
}

Received 20 September 2020

Accepted 1 November 2020

\begin{abstract}
.
BACKGROUND: The sanitary emergency due to COVID-19 virus obliged people to face up several changes in their everyday life because World Health Organisation (WHO) guidelines and countries' Health Systems imposed lockdown of activities and social distancing to flatten the infection curve. One of these rapid changes involved students and professors that had to turn the traditional "in presence" classes into online courses facing several problems for educational delivery.

OBJECTIVE: This work aimed to investigate the factors that affected both teaching/learning effectiveness and general human comfort and wellbeing after the sudden transition from classrooms to eLearning platforms due to COVID-19 in Italy. METHODS: A workshop, involving students and experts of Human Factors and Ergonomics, has been performed to identify aspects/factors that could influence online learning. Then, from workshop output and literature studies, a survey composed of two questionnaires (one for students and one for teachers) has been developed and spread out among Italian universities students and professors.

RESULTS: 700 people answered the questionnaires. Data have been analysed and discussed to define the most important changes due to the new eLearning approach. Absence of interactions with colleagues and the necessity to use several devices were some of the aspects coming out from questionnaires.

CONCLUSIONS: The study shows an overview of factors influencing both teaching/learning effectiveness and general human comfort and wellbeing. Results could be considered as a basis for future investigation and optimization about the dependencies and correlations among identified factors and the characteristics of the products/interaction/environment during eLearning courses.
\end{abstract}

Keywords: COVID-19, human centred design, comfort, discomfort, university lectures

\section{Introduction}

COVID-19 (also named 2019-nCoV or 2019 novel coronavirus) [1] grew quickly from its first emergence to a truly global phenomenon [2] becoming a

*Address for correspondence: Alessandro Naddeo, Department of Industrial Engineering, University of Salerno, Via Giovanni Paolo II, 132, 84084 Fisciano, Salerno, Italy. Tel.: +39 089 964311; Fax: +39 089 964037; E-mail: anaddeo@unisa.it. pandemic as declared by the World Health Organisation (WHO) on 11 March 2020 [3].

This sanitary emergency obliged people to face up suddenly several changes in their way of life because WHO guidelines and countries' Health Systems imposed lockdown of activities and social distancing to flatten the infection curve. One of these rapid changes involved schools and universities and, consequently, students and professors $[4,5]$ : with the sudden 
lockdown of universities and colleges around the world, they had to turn the traditional "in presence" classes into online courses [4-6]. This closure forced to solve several problems, such as the complexity to set up remote laboratories [7], to adapt complex/ traditional lessons in eLearning format [4, 8-10], having lack of resources, difficulties (accessibility and bandwidth) in Wi-Fi connections, and lack of training among students and faculty members [9] about eLearning platforms and their capabilities.

Moreover, transforming learning is a complex activity that frequently necessitates reconsideration by professors of what constitutes 'teaching' and 'learning'. It requires in-depth reasoning about the goals of any intervention, the design of the evaluation and the interpretation of the results within the particular educational context [11]. Sometimes there could be no differences in learning between classroom teaching and online teaching, even though online learning can be complicated for some subjects [12].

As a matter of fact, even though eLearning implies connectivity in the global world, at the same time, it implies distance [4]. This physical absence, that is the separation of learners and professors, is called "transactional distance" [13], and profoundly affects both teaching and learning [14-16]. With separation, there is psychological and communications space to cross, a space of potential misunderstanding between the inputs of instructor and those of the learner time [13]. Despite these aspects, the eLearning is growing faster thanks to the combination of low cost, high convenience, and accessibility $[17,18]$.

New technologies play a fundamental role in present Educational systems, and it is common sense to admit that using technology in the educational process actually changed learning. The most agreed upon directions are: communication evolution, expanding audience, collaborative learning, multitasking, rapid access to information, random access to information (hyperlink), image versus text [15]. Currently, students use technology as an integral part of their everyday lives. Of most interest is the fact that they extensively use technology for Internet searching, socializing and communication. It becomes quite obvious that students are deeply aware of the changes brought over by the digital technologies, by their impact on the learning process. Moreover, several researchers had conducted the research related to students' perception on online learning before the COVID-19 pandemic [10, 14-16], stating that the inclusion of technology in education at the university is beneficial [16]. A study of Girik [5], developed during the pandemic, shows that learners/students certainly have their perception of online learning and are deeply aware of the changes brought over by the digital technologies influencing the learning process.

Moreover, on one side, being connected at home, that is working or studying at home, could be beneficial in general. For example, people could have more control on their work-life balance [19], or avoid taking public transport or driving to reach the classroom or the workplace, saving more personal time. However, on the other side, being forced to remain at home can lead to feelings of isolation [19, 20]. Being able to talk with other colleagues or classmates is not an aspect to neglect.

Furthermore, the house sometimes could not be suitable for smart-working (teaching) or attending eLearning courses; indeed some people have to deal with the bad ergonomics of working at the kitchen table or managing the constraint time for family or children [21]. For example, some distractions could arise, such as television, phone calls, pets wanting attention, barking, climbing on furniture, or being noisy, family visitors, disturbance from doorbells, washing machines, or vacuum cleaners, noise from stereos, radios, tape players, or musical instruments, feelings of tiredness and restlessness [22-27]. The use of technology can be a source of distraction [28-32] since technological devices could present an easy outlet for coping with negative experience and boredom during homework completion [29], especially for "multitasking generation" [33]. An ongoing text exchange with a friend, for example, can be an appetitive activity that induces positive effect that offsets the boredom of homework [34].

Besides, spending the majority of the time sitting is an important aspect that can affect the learning [35-39]. Assuming uncomfortable and awkward body postures can decrease a student's interest in learning, even during the most stimulating and interesting lessons [40-47]. Adopting the eLearning approach implies the use of several devices, such as laptop, PC, telephone, smart TV, so additional risks for postural discomfort have been introduced especially for the neck [48]. Indeed, in general, it is recommended to vary the position in the workstation or postures to reduce postural diseases $[49,50]$.

Also, the combined environmental factors of light, sound, and temperature in an environment [43, 51-55] could influence student learning, mood, and performance during online courses [56] on learning [57], and on perceived levels of (dis)comfort [58]. 
However, there are no studies that investigate the effect of the sudden transition from a classroom to an eLearning platform without previous experience or specific training. This paper aims to investigate the factors that affected both teaching/learning effectiveness and general human comfort (characterized by the satisfaction of one's need [59]) and wellbeing (a psychological state [59]), after the sudden transition from classrooms to eLearning platform due to COVID-19 in Italy.

\subsection{A reference model}

Both teaching/learning effectiveness and wellbeing were considered as aspects of human perception. Also, learning effectiveness can be quantified and evaluated through tests or exams but this quantitative aspect has been neglected in this study since the focus is on factors individuation. Thus, the Naddeo et al. [60] reference model of comfort/discomfort perception was used in order to identify all the factors that affect both teaching/learning effectiveness and general human comfort and wellbeing, and to organise them in clusters; in this work [60], comfort and discomfort perceptions had been analysed and modelled [61] in the form of a matrix of macro-factors divided into four classes:

1) Human's characteristics that are, for instance, physical characteristics, mental state, personal data, lifestyle and expectations.

2) Tools and products characteristics with which people interact and that affect the (dis)comfort perception [62, 63]. In this study, these factors concern aspects related to the work-station/seat characteristics, the furniture around the student/ teacher, the tools handled by people like books, pen/pencil, paper sheets, mouse and keyboard, devices like PDA, tablet, smartphone or deskcalculator, etc.

3) Tasks' characteristics describing the interaction between a human and the activity that he/she performs; these concern aspects related to the type of activity/task and the tools' parts with which the user has to interface for the task's execution. For the work-station/seat, both the assumed posture to perform the task and the type of personal equipment have been considered to characterise the specific interaction.

4) Characteristics of the work environment. Comfort and wellbeing in a work environment are influenced by several factors: workspace interpreted both as physical space dedicated to work [64] and as plant/office layout, the state of maintenance of the environment (cleanliness and order) and all the aspects related to olfactory, visual, acoustic, thermal characteristics of the work environment.

Starting from the Naddeo et al. comfort model [60] and using the general clusters to the specific case (online teaching/learning), the research question is: Which are the factors that affected both teaching/learning effectiveness, general human comfort and wellbeing, after the sudden transition from classrooms to eLearning platforms due to COVID-19 in Italy, and how?

\section{Materials and methods}

\subsection{Procedure}

This study was carried out strictly in compliance with the Ethical Regulation the University of Salerno. The research process can be schematized in two steps starting from the research question (see the schematization in Fig. 1):

1) Survey development through a workshop to identify aspects/factors that could influence online learning in terms of comfort, wellbeing and learning/teaching effectiveness.

2) Survey output analysis for giving an overview of these factors and answering the research question.

First of all, a brainstorming among mid and high experienced people in the field of Human Factors and Ergonomics topics was conducted in the form of a workshop for the identification of all the aspects/factors that could influence online learning. The output of the workshop was an extensive survey composed of two online questionnaires (about 130 questions in total), one for students and one for professors, composed by closed-, semi-closed and openquestions. The questionnaire development was done taking into account the Tourangeau model [65] for interviewer answer process, that is considering the four cognitive stages or process while answering the question: comprehension of question, recall of memories, retrieval and judgment for attitude questions, the translation of judgments into responses. Pilot tests were conducted and a screen of questions was done to minimize survey errors (variance and bias) [66-70]. The questionnaires were spread out among Italian universities obtaining more than 700 


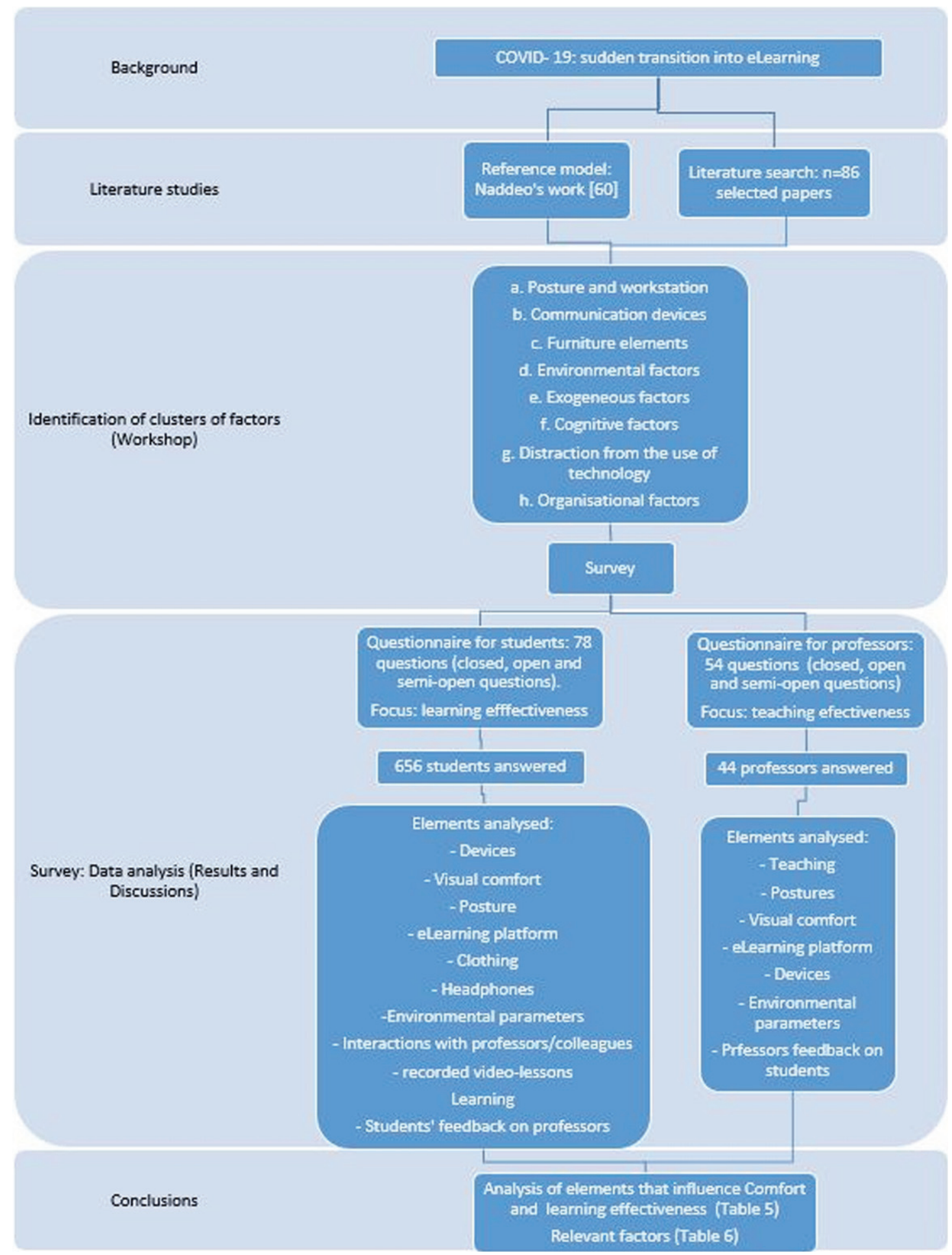

Fig. 1. Schematization of the research process.

answers (656 students and 44 professors, as shown in Fig. 2 and Fig. 3). This number was enough to conduct qualitative research in which statistics were not used to analyse the data. The identified factors were compared with a wide literature search and several overlapping among them were verified. 


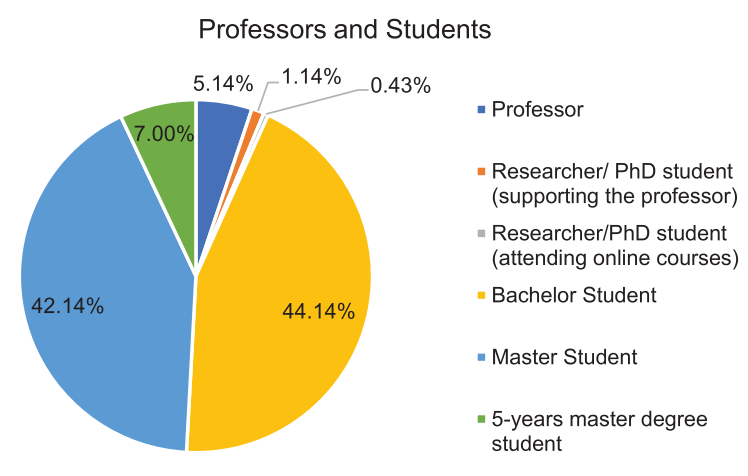

Fig. 2. Percentages of students and professors.

\subsection{Identification of clusters of factors}

A workshop was planned in order to answer the question "which factors influenced, positively or negatively, student's comfort during online learning?". Before the workshop, a first brainstorming between professors and experts, was accomplished to identify the involved macro factors (or clusters) in online learning. The output of the brainstorming was the definition of the following 8 clusters of factors:

a. Posture and workstation [35-46, 48, 50, 61, 71-80]: aspects related to the characteristics of the utilized workstation and the assumed posture during online learning.

b. Communication devices $[4,9,11]$ : all aspects related to the type of communication devices used. c. Furniture elements $[19,38,41-46,48,57,71]$ : furnishing factors (the ones in the room but not the workstation) that influence the perceived comfort of the working environment.

d. Environmental factors [25-27, 51-55, 58, 81]: such as temperature, lighting, humidity, etc.

e. Exogenous factors [21-24]: external influences related to people life, such as the other people living in the same house.

f. Cognitive factors $[4,7,8,11,13,20,53-55,82]$ : characteristics of the person that affect performance and learning.

g. Distraction from the use of technology [4, 28-34]: the use of devices could be a source of distractions.

h. Organisational factors [7, 19]: all the aspects regarding the re-organisation of time dedicating to the study and time dedicating to the recreative activity.

This list of clusters was meant to create a guideline where all people involved in the workshop could share their knowledge (based on scientific background and literature overviewing) and to reflect on their own experience.

\subsection{Workshop}

Thirty-five students and five experts in the field of Human Factors and Ergonomics were involved in this workshop. Students were selected among those that were involved for more than one month in online

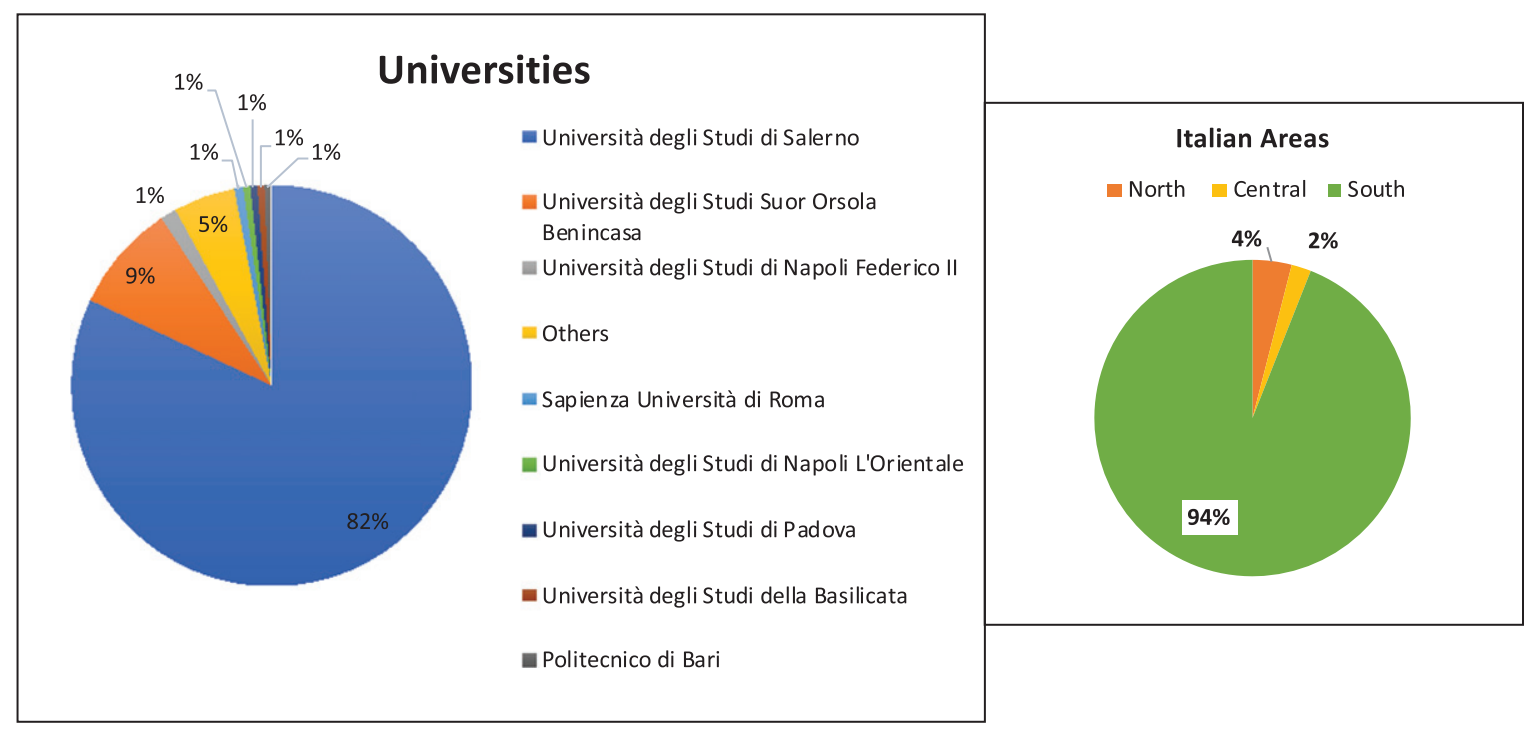

Fig. 3. Information about Italian universities. On left there are specifications about universities. On right, specifications about Italian areas. 
learning activities and had previous experience in the field of "Human Factors and Ergonomics". Among the experts, two professors led the workshop. The workshop's activities were accurately coordinated involving students, experts and teachers. In particular, the activities were organised in order to increase self-determination and intrinsic motivation following the guidelines of Reeve, et al. [83], to highlight and promote the autonomy of thinking as shown in the work of Scharle and Szabó [84], and finally to apply the "8d Model" of problem-solving as in Duffy [85].

The project-based learning (PBL) [86] was used as a learning model to engage students and experts using their experience and knowledge for the screening of factors and the questionnaire creation. Mindmapping and brainstorming were the used techniques. These techniques are easily usable in an online discussion environment.

So, these workshop activities were organised in several sessions in which students, experts and professors worked both individually and in groups developing the sub-activities. During the workshop, several tasks were assigned to students:

1. First, each student was asked to write down independently (in 20 minutes) a list of factors that were influential on perceived comfort per their personal experience. In this way, it was ensured that the students did not influence each other and were able to express their personal feelings [84].

2. Then, students were divided into six groups (each group was under the supervision of a professor or a researcher or a $\mathrm{PhD}$ student) and were asked to discuss (for 20 minutes) within the group about their personal factors. Only in this phase, the students belonging to the same group interfaced with each other, and, with a group brainstorming, they compiled a second list of factors. They discussed the factors highlighted by each member of the group, eliminating the redundancies, and, in some cases, removing or adding factors [85].

3. Thenceforth, students were instructed about the macro factors (or clusters, the list aforementioned) and each group was asked to organize (in 20 minutes) the identified factors in clusters. It was also allowed to report the same factor in multiple clusters if it was necessary [86].

4. Once the identified clusters were filled with info and factors, the partial results were the following: a. Posture and workstation: Brainstorming and mind-mapping allowed to identify several factors in this cluster: the workstation/seat characteristics, the elements that they interact (for example many students reported the headphones as an integral element of their workstation), layout and organisation of the work area. Regarding the posture, the subjects considered not only the type of posture assumed but also the amount of time spent in each position.

b. Communication devices: Many factors that during the use of specific devices affected the perceived (dis)comfort were detected: the quality of the internet connection, the Larsen effect, the technical characteristics of the used device (screen size, PC peripherals, etc.).

c. Furniture elements: In this cluster, students reported other furniture elements (different from the seat-desk normally utilized) that seemed to affect the perceived (dis)comfort, such as room acoustic problems, auxiliary components of the workplace (such as tables, shelves), use of multiple screens, etc.

d. Environmental factors: In this cluster, the focus was centred on the environmental factors that, according to students, affected, positively or negatively, the perceived wellbeing. Among factors, the following were highlighted: the state of maintenance of the environment, the lighting conditions, the air quality and the noises.

e. Exogenous factors: Sharing the work environment with family or colleagues may involve several exogenous facts affecting the perceived wellbeing. The most influencing were the noises from inside and outside; nevertheless, other factors have been considered.

f. Cognitive factors: This cluster proved to be the most populated compared to the others. Therefore, it appeared that the new learning modality had a significant impact on the cognitiveemotional aspects. Some aspects are: the different way of interacting with professors, the absence of colleagues, a different level of attention required during online lessons, the absence of trips (usually with own or public transport) to/from university are.

g. Distraction from the use of technology: The new online learning method allowed students to use different lesson support tools during the lesson: use of technological and non-paper devices to take notes, use of search engines during lessons for further information or clarifications in real-time, the possibility to record 
lessons; all of them were beneficial for learning effectiveness but, on the other hand, could be a source of distraction.

h. Organisational factors: In the last cluster, the aspects regarding the re-organisation of time dedicated to the study and time dedicating to other activities (like recreative ones) were considered. Arranging everything to attend properly online classes had a remarkable impact on the student's wellbeing. Indeed, students had to change their habits and the way to schedule a study day. The suddenly increased freedom to move during the lesson could be considered a positive factor for some students (an increase of the wellbeing and consequently of the quality of learning) while, for others could have a negative impact (greater freedom implies a greater distraction factor). Some could consider the less time between one lesson and another (for example, due to the time usually needed to change the classroom) as time gained (for study), while for others a stress factor because there is no time to regenerate themselves.

5. In the fifth part of the workshop, one or two clusters were assigned to each students group and advised by an expert. Each group had the task to combine (in 20 minutes) all lists just realised (point 4) to obtain one detailed considered aspects' list for each assigned cluster. Within the clusters, redundancies were cancelled. Moreover, since it was allowed to report the same factor in multiple clusters, each group separated the factors/aspects that seemed not belonging to the assigned cluster.

6. With a final brainstorming session, each group described and discussed each assigned cluster figuring out the undecided factors/aspects for them.

7. At the end of the workshop, each group owned a cluster, and the list of factors/aspect to examine. With this basis, each group had the assignment to write down a list of questions enlightening positive and negative factors that can influence learning, wellbeing and postural comfort, respectively.

The goal of the workshop was reached with an online plenary session where the group leaders discussed their questions for the survey. Thanks to this last brainstorming, the survey was realised, analysed, discussed, and pilot-tested. Since the survey was addressed to university students and professors, two similar questionnaires were created considering the differences in the online-learning approach.

\subsection{Survey development}

The original language of the survey was Italian, and results have been translated in English for this paper. The survey was split into two different questionnaires realized with Google Forms platform: the first for students and the second for professors. The first set of questions was common to everyone and was meant to cluster the respondents per:

- Gender

- Age

- University they attend or work at

- The role they assume in the online courses (professor, researcher/PhD student (supporting the professor), researcher/PhD student (attending online courses), Master student, Bachelor student, five-years Master degree student)

Then, according to the assumed role, respondents were directed to the second set of questions dedicated to Students (composed by 78 questions, closed-, open-, and semi-open-questions) or to Professors (composed by 54 questions closed-, open-, and semiopen-questions). The questionnaires were similar to each other but presented one main difference: while for students, it was more important to understand the influence on learning, for professors, the concern was more on their teaching effectiveness.

\section{Results and discussions}

Seven hundred people answered the questionnaires, 656 students and 44 professors (see Fig. 2), 394 males and 306 females (almost equally distributed in gender). Table 1 shows statistical information of the students and professors age: the median age for students was 22, while for professors 46 . Figure 3 shows detailed information about addended universities: most respondents belonged to Southern Italian universities.

Table 1

Statistical information about the age of students and professors

\begin{tabular}{lccccc}
\hline & Mean & Median & $\begin{array}{c}\text { Standard } \\
\text { deviation }\end{array}$ & Min & Max \\
\hline $\begin{array}{l}\text { Only professors } \\
\text { (AGE) }\end{array}$ & 44,55 & 46 & 10,53 & 24 & 68 \\
$\begin{array}{l}\text { Only students } \\
\text { (AGE) }\end{array}$ & 22,73 & 22 & 2,71 & 18 & 53 \\
\hline
\end{tabular}


GENERALLY, HOW MANY HOURS A DAY DO YOU USE ELECTRONIC DEVICES (COMPUTER/TABLET/MOBILE PHONE) TO ATTEND ONLINE LESSONS?

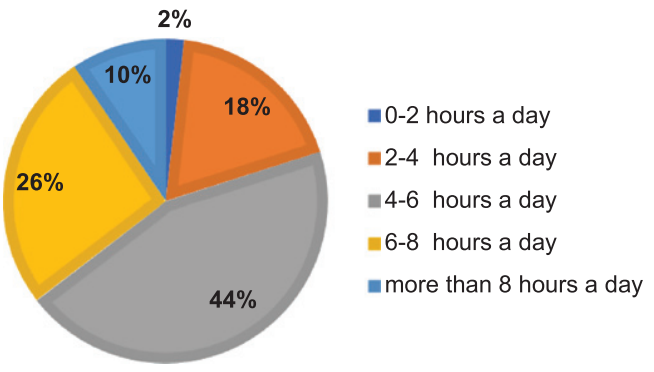

Fig. 4. Hours per day spent to attend online courses.

The following sections discuss in detail the gathered information; the percentage are always referring to the answers related to the number of students and professors, respectively.

\subsection{Students}

Among the 626 Italian university students, 64\% followed online university courses during COVID19, 5 days a week using electronic devices (computer/ tablet/mobile phone) for approximately 4-6 hours a day (44\%, Fig. 4). Student's life had become more sedentary $(84.45 \%)$, and they expressed the need to have a comfortable seat and workstation considering the different elements that emerged from the survey. Indeed, $88 \%$ agreed that the chair type is important to ensure a good level of perceived comfort; and, $80 \%$ stated that the desk represents an important element for the comfort and effectiveness of learning. The main elements that can influence wellbeing and learning during online courses are described below.

\subsubsection{Devices}

$57 \%$ of students stated that they used multiple electronic devices simultaneously, while $43 \%$ used only

\section{A SUFFICIENTLY LARGE SIZE OF YOUR SCREEN DURING THE ONLINE LESSON POSITIVELY INFLUENCES LEARNING EFFECTIVENESS}

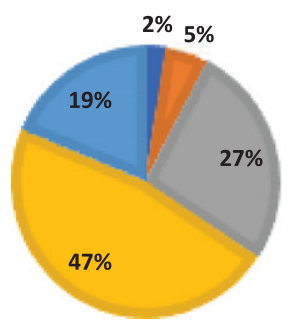

one electronic device during eLearning. The most used devices were the personal computer (95\%) and smartphone $(33 \%)$ while the tablet and smart TV reached $8 \%$ and $2 \%$ respectively. $73 \%$ of them owned a personal PC, $7 \%$ shared it equally with another user, while $17 \%$ shared it with others but mainly used it.

Since the percentage of those who used the PC is highest, the results regarding the screen size and its correlation with postural comfort and learning were relevant. The questionnaire asked if a sufficiently large screen size, during the online lesson, could POSITIVELY influence learning effectiveness and postural comfort. The results, rating on a 5-point Likert scale that goes from very disagree to very agree, are shown in Fig. 5. Most of them agreed that a sufficiently large size of the screen positively influences learning effectiveness (about 66\%) and postural comfort (about 79\%).

During online lessons, $44 \%$ of the interviewed stated they used electronic devices (computer/tablet/ mobile phone) for $4-6$ hours a day; $26 \%$ for $6-8$ hours a day; $18 \%$ for $2-4$ hours a day; $10 \%$ more than 8 hours a day and only $2 \%$ less than 2 hours a day (Fig. 4).

Has too much time spent utilizing a device affected learning adversely? Regarding this factor, the results are shown in Fig. 6: about 65\% agreed, 22\% was indifferent and about $13 \%$ disagreed.

During online lessons, moreover, about $56 \%$ used electronic devices also for taking notes: of these, $17 \%$ used them very often and 39\% for few times. The remaining (44\%) used electronic devices, exclusively to follow lessons. Indeed, only $31 \%$ stated that the use of electronic devices to take notes is comfortable. The new way to attend lessons gives students the possibility to use the online search-engines (Internet) during the lessons, in case of doubts or some unclear concepts. Among the people who participated in the

\section{A SUFFICIENTLY LARGE SIZE OF YOUR SCREEN, DURING THE ONLINE LESSON, POSITIVELY INFLUENCES POSTURAL COMFORT}

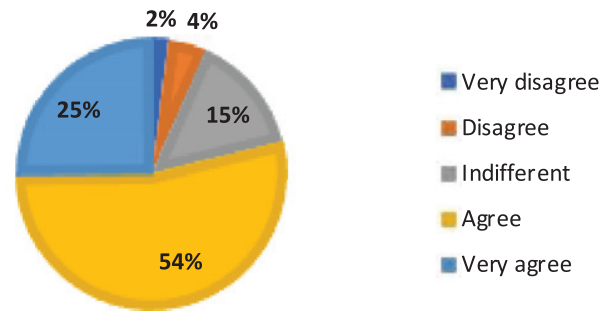

Fig. 5. Influence of size screen on learning effectiveness and postural comfort. 


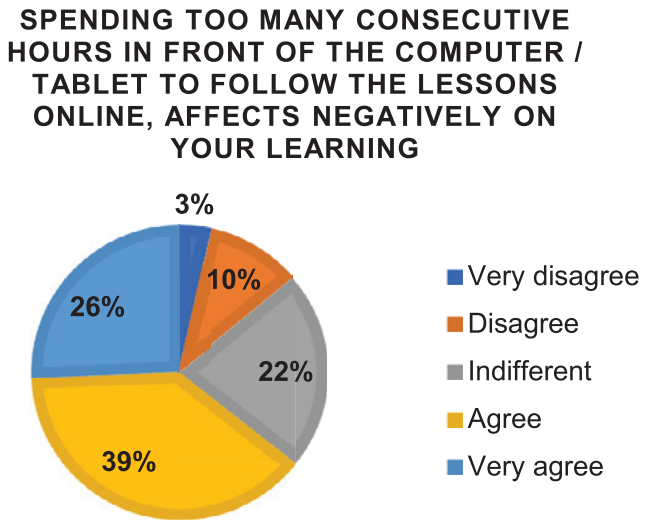

Fig. 6. Influence of time on learning.

survey, the percentage of those who used the search engines very/very much is equal to $28 \%, 39 \%$ used them few times, and about $33 \%$ used them for nothing or very little. In the survey, it was asked whether the use of search engines during the lesson could negatively influence the overall effectiveness of learning. To the statement "The use of search engines during the lesson (in case of doubts) NEGATIVELY influences learning effectiveness", on a 5-point Likert scale (from very disagree to very much agree) $38 \%$ disagreed with this statement, $32 \%$ was indifferent, $30 \%$ agreed.

\subsubsection{Visual comfort}

Since prolonged use of the electronic device (PC) can affect visual comfort, to improve visual wellbeing, students moved the monitor away (46.49\%), tilted the monitor (51.68\%), varied their posture (40.40\%), adjusted the brightness of the room or the PC monitor (59.60\%). Another element that could influence visual comfort was the size of the screen or the use of a single screen. Indeed, $98 \%$ of students stated to have difficulty following online teaching with a single screen.

\subsubsection{Posture}

The survey found that over $90 \%$ of the students attended the lessons sitting on a chair. Differentiating the office chair from an ordinary chair (kitchen chair, folding, etc.), it emerged that almost $60 \%$ used the ordinary chair and 38\% used the office one. Moreover, for the chair users, it had been asked which were the chair characteristics that were essential to improve the perceived comfort during the lessons (it was a semi-closed question with the possibility to choose more alternatives). The responses were mainly concentrated on the armrests $(51,22 \%)$, height adjustment $(57,16 \%)$, lumbar support $(54,57 \%)$, and backrest (63,72\%), as shown in Fig. 7.

The study/work station used was considered quite comfortable. On a 5-point scale from 1 (minimum comfort level) to 5 (maximum comfort level), the responses were concentrated between 2 and 4, as shown in Fig. 8.

The survey shows that only $14 \%$ of respondents never experienced any complaint, while $86 \%$ experienced annoyance for too much time spent attending online lessons. In particular, about $32 \%$ experienced discomfort after more than three hours, $25 \%$ after more than 2 hours, $13 \%$ after more than an hour, and

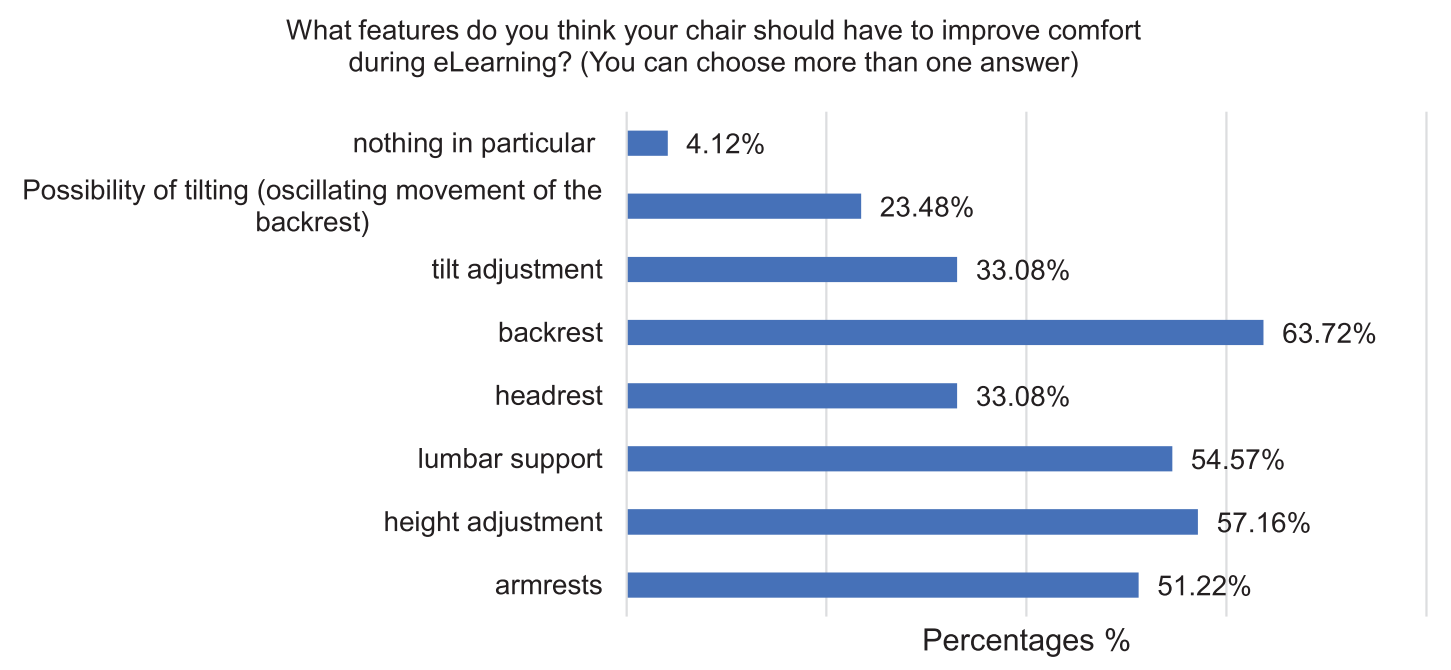

Fig. 7. Percentages of essential chair feature to improve perceived comfort during eLearning lessons. 
Considering your study / work station, which is your postural comfort level on a 5-point scale?

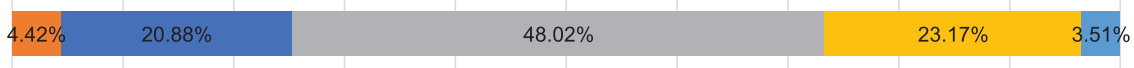

$\square 1$ - No comfort $\square 2$ - Slight comfort $₫ 3$ - Comfort $\square 4$ - High comfort $\square 5$ - Extreme comfort

Fig. 8. Percentages of perceived comfort level, rated on a 5-point scale.

$15 \%$ always. To cope with this annoyance, almost the totality of students got up during the lessons to stretch his legs. Furthermore, one of the most frequent actions was the change of posture while remaining in the same position $(64 \%)$.

\subsection{4. eLearning platform}

The used platform proved to be a good solution to face the sanitary emergency of COVID-19. Indeed, about how often they encountered problems related to the platform malfunctions, the percentages are: $9 \%$ never, $43 \%$ rarely, $37 \%$ few times, $11 \%$ often, $2 \%$ always. According to platform users, the problems were mainly caused by an inefficient internet connection (76\%) and a large number of online classes (27\%). Moreover, with other questions, it had been found out that the most used type of connection is the WiFi one $(85,43 \%)$ which had a high frequency of line problems in a week (often 90\%). This aspect led on a negative influence on learning, as shown in Fig. 9: students were asked to rate on a 5-point Likert scale the level of agreement/disagreement respect to the expressed question. About $80 \%$ agreed that the problems, even momentary, of audio/video connection could affect their learning negatively.

\section{The problems, even momentary, of audio/video connection affect your learning NEGATIVELY}

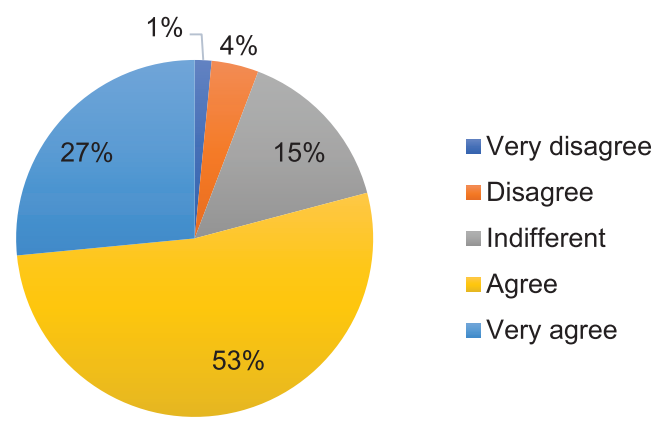

Fig. 9. Percentages of the level of agreement/disagreement of the negative influence of bad connection on learning.
Table 2

Influence of clothing on perceived comfort

\begin{tabular}{llc}
\hline \multicolumn{3}{c}{$\begin{array}{c}\text { Do you think the influence of clothing on your } \\
\text { comfort during the online lesson is relevant? }\end{array}$} \\
\hline \multicolumn{2}{c}{ 5-point scale } & Percentages \\
\hline Irrelevant & 1 & $14,37 \%$ \\
\multirow{3}{*}{ Relevant } & 2 & $10,36 \%$ \\
Very relevant & 3 & $23,18 \%$ \\
& 4 & $34,78 \%$ \\
\end{tabular}

\subsubsection{Clothing}

Considering that generally, during the lessons, the students could deactivate the webcam, only about $20 \%$ of the sample declared to adopt completely different clothing from what is usually worn during the lessons in the classroom (underwear and nightwear). The rest of the students, however, had equally adopted clothing typically used during class lessons. In increasing order, the percentages were sports $(47.56 \%)$, informal (sweatshirt, T-shirt, jeans, $31.40 \%$ ), nightwear (18.90\%), formal (trousers, shirt, $1.22 \%$ ). In addition, the influence of clothing on the perceived level of comfort was also investigated. On a 5-point scale, from 1="minimum influence" to $5=$ "maximum influence", $75 \%$ of students answered that clothing is relevant for comfort, while the $24 \%$ did not consider it relevant as shown in Table 2.

\subsubsection{Headphones}

During a Video Teleconferencing (VTC) $51 \%$ of the sample used the speaker of the device, $41 \%$ the headphones, and only $8 \%$ used external speakers. Among people that regularly used headphones, due to noises in the workplace, $41 \%$ used them 1-3 hours a day, 42\% 4-6 hours a day, 15\% 6-9 hours a day, and only $2 \%$ over 9 hours a day. Figure 10 shows the percentage of choice of respondents regarding the discomfort caused by the consecutive use of the headphones, expressed in hours. 
IF YOU USE HEADPHONES, AFTER HOW LONG DO YOU EXPERIENCE DISCOMFORT DUE TO THEIR EXCESSIVE USE?

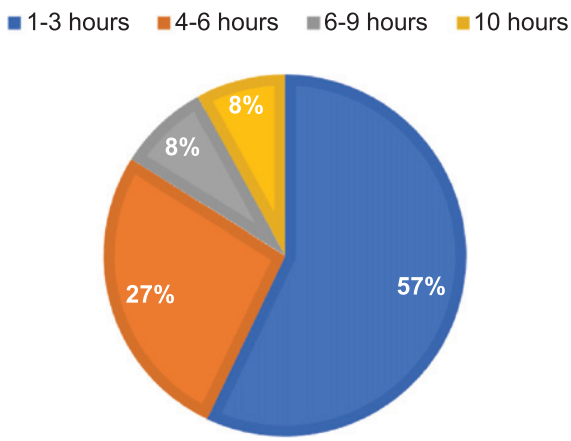

Fig. 10. Percentages of time when discomfort of using headphones is arising.

\subsubsection{Environmental parameters}

All respondents declared to attend online lessons in their own home (since going out during the lockdown meant to be punished with a fine). Consequently, they were asked to rate the environmental parameters in their workplace according to their perception (on a 5-point scale). Results are shown in Fig. 11: the environmental parameters (air quality, temperature, ventilation, lighting) scored values between Good and Great (4 and 5 values on the 5-point scale).

Staying at home, everyone had the opportunity to control, according to their preferences, all environmental factors (air quality, temperature, ventilation, lighting, and order/cleanliness). Therefore, the authors wanted to investigate whether the possibility of being able to control these factors had a positive impact on learning and physical wellbeing. In Table 3 are shown the results to the statement "the possibility of being able to control environmental parameters positively influences your physical wellbeing and your learning", rated on a 5-point Likert scale that goes from very disagree to very agree. In Table 3, for more clearness, the results have been grouped into one negative group (very disagree, disagree, indifferent) and positive group (agree, very agree): higher values are on "agree-very agree" group. Thus, controlling environmental factors had a positive impact on learning and physical wellbeing.

The presence of noises was another environmental factor considered in the survey. Noises were clustered in two main sets: indoors and outdoors. The first one included the noises inside the workplace, deriving both from the presence of other people in the work environment and from objects (household

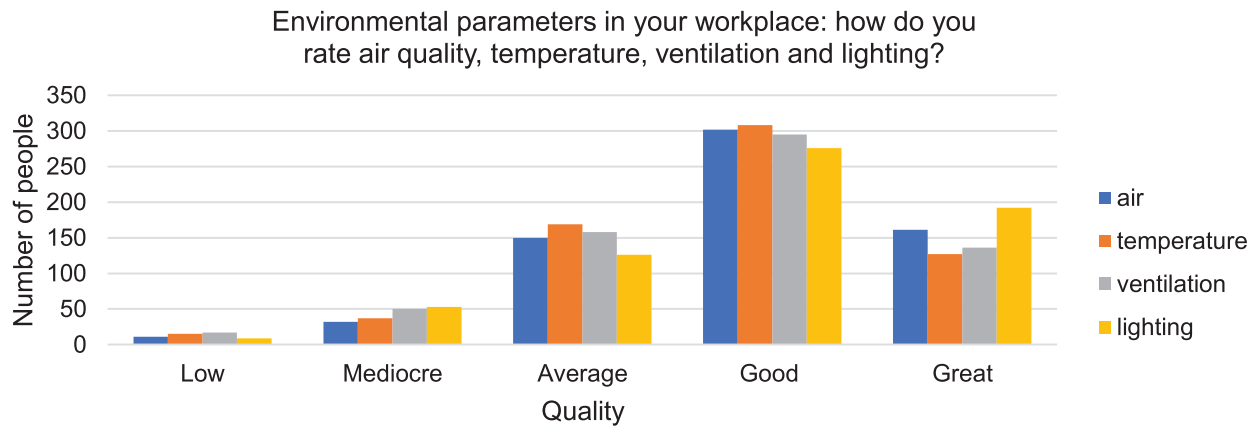

Fig. 11. Quality of the environmental parameters.

Table 3

Influence of environmental parameters control on physical wellbeing and learning. For more clearness, the results have been grouped into one negative group (very disagree, disagree, indifferent) and positive group (agree, very agree)

\begin{tabular}{lcccccc}
\hline & Part of scale & Air & Temperature & Ventilation & Lighting & $\begin{array}{c}\text { Order/ } \\
\text { cleanliness }\end{array}$ \\
\hline Physical wellbeing & $\begin{array}{c}\text { Very disagree- } \\
\text { disagree- indifferent }\end{array}$ & $15,09 \%$ & $12,65 \%$ & $14,48 \%$ & $10,37 \%$ & $26,83 \%$ \\
& Agree-very agree & $84,91 \%$ & $87,35 \%$ & $85,52 \%$ & $89,63 \%$ & $73,17 \%$ \\
Learning & $\begin{array}{l}\text { Very disagree- } \\
\text { disagree- indifferent }\end{array}$ & $23,02 \%$ & $16,92 \%$ & $23,63 \%$ & $12,96 \%$ & $33,99 \%$ \\
& Agree-very agree & $76,98 \%$ & $83,08 \%$ & $76,37 \%$ & $87,04 \%$ & $66,01 \%$ \\
\hline
\end{tabular}




\section{The presence of internal and external noises influence your learning during online courses:}

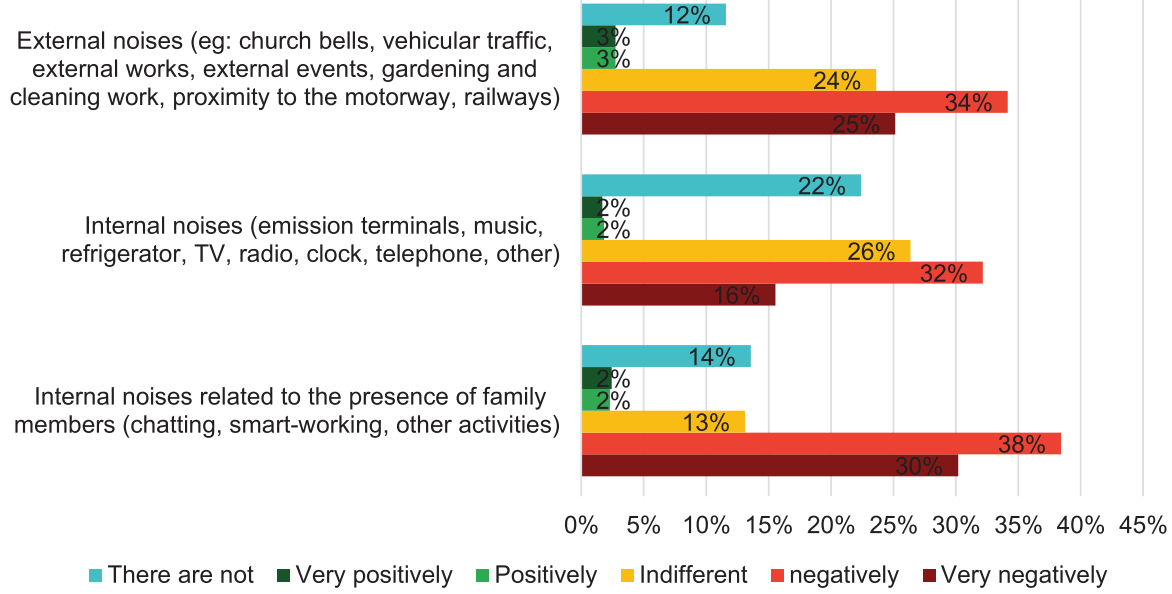

Fig. 12. Influence of noises on learning rated on a 5-point scale.

appliances, television, etc.). The second one included noises coming from outside, such as city noises, traffic, motors, road works. Respondents declared these noises NEGATIVELY affected learning. The percentages are shown in Fig. 12.

\subsubsection{Interactions with professors/colleagues}

The lack of direct interaction with professors/ colleagues had been individuated as one of the factors affecting comfort and effectiveness in the new e-learning environment. Thus, people were asked about the positive/negative influence of this aspect. It was also connected to the attitude (shy or cheeky) of students while interfacing themselves with the professors.

Since online lessons gave the possibility to disable the webcam (in many cases it was necessary due to the crowded classes, to avoid connection problems on the used eLearning platform), it was asked whether disabling the webcam facilitated interactions with professors. On a 5-point scale, from very much to very little, the respondent gave the following answers: $9 \%$ of the sample believed that deactivating the webcam facilitated very much interactions with professors; $22 \%$ very; $26 \%$ enough; $28 \%$ little and $15 \%$ very little. This aspect, probably, is mainly due to the shyness factor. When asked "do you think you are shy", $8 \%$ of the sample thinks they are very much shy; $14 \%$ very; $36 \%$ enough; $31 \%$ little and $11 \%$ very little.

The survey also investigated on how important was the direct student-professor interaction. On a 5-point scale from very important to unimportant, Fig. 13

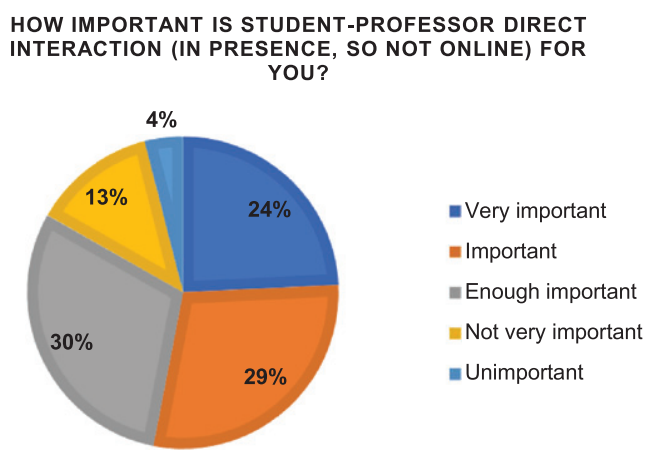

Fig. 13. Importance of direct contact with professor for students.

shows the percentages of answers. About $53 \%$ of them declared the direct interaction student-professor is important, $30 \%$ is indifferent, while for only $17 \%$ it is not important.

Then, two more questions, as shown in Fig. 14, were asked to assess whether this aspect was somehow related to learning effectiveness. In their opinion, the lack of direct interaction with the professors influence moderately (30\%) their learning, since the visual contact influence very much $(28 \%)$ the effectiveness of learning.

With the advent of the sanitary emergency of $\mathrm{CO}$ VID-19, students have found themselves isolated in their houses, without any direct contact with colleagues. This aspect should not be underestimated, as it was considered relevant for students. With the question "How important is it for you to confront with your colleagues during lessons?", the survey 


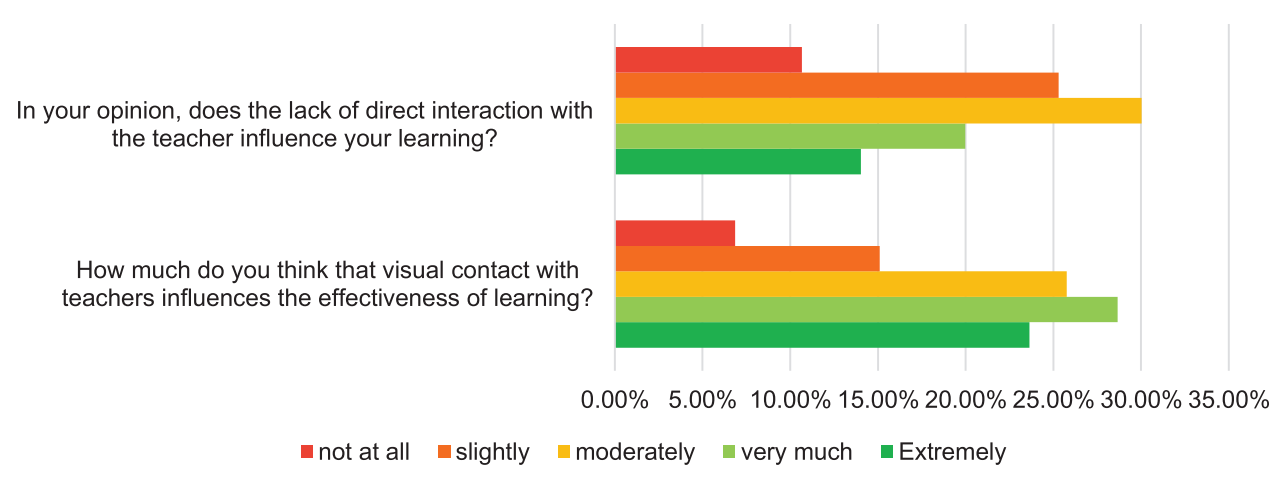

Fig. 14. Importance of visual contact or direct interaction on learning.

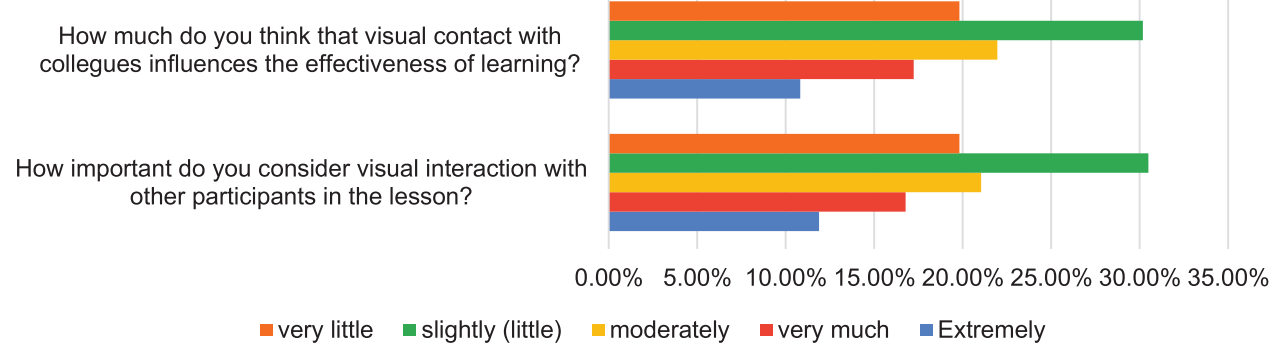

Fig. 15. Importance of interactions with colleagues.

highlights that: $30 \%$ of students considered the opportunity to consult each other extremely important, $29 \%$ a lot and $26 \%$ quite important. $12 \%$ answered little and only $3 \%$ very little. Figure 15 shows the percentage regarding the importance, for the students, of the visual contact with colleagues.

\subsubsection{Recorded video-lessons}

The eLearning platform gave professors the possibility to record video-lessons. Out of 656 participants, only 142 replied that none of the professors allowed video recordings. However, considering which effects had video recordings on students learning, results showed that only $19 \%$ of the sample considered the possibility of having video recordings as a distraction factor, while for the others the video recordings caused very little or not at all distractions. Conversely, audio-video recordings were useful for learning purposes for $79 \%$ of the sample, while for $14 \%$ it was indifferent, and only $6 \%$ believed that video recordings were not useful for learning purposes. About the usability of the online lessons, people satisfaction is shown in the graph of Fig. 16: higher rates are between moderately (47\%) and very (35\%) satisfied.

\subsubsection{Distractions}

Having more freedom could also mean more distractions. Among the reasons for distractions, the phone-calls received during the lesson, the time dedicated to games, browsing between various websites and social media were considered in the survey

Table 4

Distraction factors during eLearning

\begin{tabular}{|c|c|c|c|c|c|}
\hline & \multirow[t]{2}{*}{$\begin{array}{l}\text { Have you ever received } \\
\text { calls during } \\
\text { an online lesson? }\end{array}$} & & \multicolumn{3}{|c|}{$\begin{array}{l}\text { How much time do you estimate to } \\
\text { spend on the following distractions } \\
\text { during online lessons? }\end{array}$} \\
\hline & & & Social media & Games & Website \\
\hline Never & $26,07 \%$ & Never & $17,53 \%$ & $80,79 \%$ & $51,37 \%$ \\
\hline Rarely & $45,58 \%$ & Up to 5 minutes & $38,11 \%$ & $9,15 \%$ & $40,40 \%$ \\
\hline Sometimes & $23,93 \%$ & Up to 15 minutes & $30,95 \%$ & $6,10 \%$ & $7,93 \%$ \\
\hline Often & $3,81 \%$ & Up to 30 minutes & $9,60 \%$ & $2,59 \%$ & $0,15 \%$ \\
\hline Always & $0,61 \%$ & More than 30 minutes & $3,81 \%$ & $1,37 \%$ & $0,15 \%$ \\
\hline
\end{tabular}


HOW SATISFACTORY IS THE LEVEL OF USABILITY OF ONLINE LESSONS?

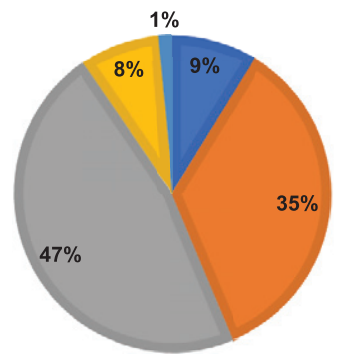

$$
\begin{aligned}
& \text { Extremely } \\
& \text { every } \\
& \text { emoderately } \\
& \text { slightly (little) } \\
& \text { every little }
\end{aligned}
$$

Fig. 16. Level of satisfaction of eLearning.

(Table 4). They rarely $(45.58 \%)$ received calls during online lesson, and used to browsing on social media $(38.11 \%)$ or websites $(40.40 \%)$ up to 5 minutes.

Considering that not all professors record the lessons (64\%), some students had a concentration comparable to the presence in the classroom, but with the possibility of focusing and listening better and more comfortably the professor. The presence of recorded lessons did not automatically induce a distraction; indeed, only $58 \%$ is distracted little, while $24 \%$ not at all. Besides, routine boredom also influenced the study $(71 \%)$ and, therefore, can lead to more distraction or listlessness.

\subsubsection{Learning}

The opportunity to attend the online lessons staying at home represented a considerable advantage for students, who do not need to go to a specific place (university) and therefore avoid the stress due to travel. $67.84 \%$ of students said that online teaching is more productive than classroom lessons because time spent on travel is recovered in other different ways (more rest, more time to review notes, etc.). Students faced lessons with less perceived stress. Indeed, $55.19 \%$ preferred online teaching to classroom teaching (16\% indifferent, $28 \%$ do not prefer it) for the absence of travel or parking problems. Furthermore, the absence of breaks or loss of time greatly influenced comfort $(61.74 \%)$ and learning $(56.86 \%)$. In addition, the freedom of movement, during the lessons, affected comfort $(73.32 \%)$ and learning $(50.15 \%)$, as students have the opportunity to organize, according to their preference, their workstation (an essential factor that influences comfort $80 \%$ and learning 63\%). $39 \%$ of students agreed on the effectiveness of the use of search engines during online lessons compared to face-to-face lessons, while $36 \%$ were indifferent to them.
The possibility of having the lessons recorded have facilitated student learning ( $80 \%$ agree). Furthermore, online lessons, generally, not represented a good solution of facilitating student learning (55\%) as there was no direct interaction with the professor which represents the ideal way to have visual and auditory feedback. This lack can accentuate the student's distraction, and the need to fill the lessons in the set time, incurring a non-stop speech by the professor. However, both with the recorded lessons and during online teaching, taking notes was better both in terms of comfort (62\%) and learning effectiveness $(41 \%)$. The reasons are: it was always possible to follow the presentations (greater clarity than in class, $72 \%$ ) during the online lessons; more time in reviewing notes (reviewing the lesson or doing research in real-time); and to use all the personal electronic devices comfortably on a dedicated or preferential workstation.

The audio/video connection problems that may arise during the lesson had a negative influence on students' learning ( $80 \%$ agreed), as well as the increase in time spent in front of the screen $(65 \%$ agreed). The performance limits of the device, such as hardware, also, negatively affected the effectiveness of learning (42\%) and psychological stress (71\%). Students had to solve the problems related to the device. At the same time, they were already subjected to stress in following the lesson, which could be avoided in a class by taking notes by hand (excluding other disturbing factors such as distance from the blackboard).

Furthermore, even from this survey, it is confirmed that the static nature of the workstation affected mental fatigue $(71 \%)$, as already found in the literature [54]. Another very negative aspect that emerged, is the worsening of group activities; indeed, $72 \%$ of students said online teaching has negatively affected this. The interaction should be improved.

\subsubsection{Students' feedback on professors}

Interviewees were asked to give feedback about professors to understand how professors' teaching is perceived in the perspective of students. $70.73 \%$ said that professors respected the established timetable, waiting for the majority of the class to be connected. Also, professors tended to finish at the scheduled time or a few minutes before $(63.41 \%)$, trying to respect the scheduled calendar. Moreover, in case of further explanations, students perceived that there was a little more flexibility ( $32.77 \%$ or fair $25.61 \%$ ) compared to classroom teaching. Students considered important 
(74.48\%) the break between successive lessons, such as to have an adequate level of comfort $(76.98 \%)$ and efficiency $(71.41 \%$ ) in learning (break seems to facilitate learning by improving the ability to concentrate). However, 59.91\% of students affirmed that professors never consider whether they had a proper break within lessons. In addition, an adequate break within the same lesson was desired for a recovery in terms of comfort $(74.23 \%)$ and learning effectiveness $(73.17 \%)$. The presence of online teaching did not change the pre-existing office hours between professors and students and the availability of professors.

\subsection{Professors}

\subsubsection{Teaching}

The survey showed that $66 \%$ of professors were engage in online teaching 3-4 days a week, taking from 2-4 hours a day (36\%) or more than 8 hours a day $(30 \%)$. In the survey, they had been asked how they prefer to conduct a lesson: $85.11 \%$ seated; $8.51 \%$ walking; $6.38 \%$ standing. Since they usually conducted the lesson with the camera on, it was usual to dress in informal (sweatshirt, T-shirt, jeans; $52.27 \%$ ) or formal (trousers, shirt; 36.36\%) suits. Professors agreed $(63.64 \%)$ that audio and video connection problems negatively affected teaching, as well as the percentage of time spent in front of the screen $(59.09 \%)$.

The lack of eye-contact between professor and students is very important (66\%). In fact, in the open question "what would you improve in online teaching", $15 \%$ ask for an improvement in real-time student feedback to act promptly, along with the addition of technical equipment (43\%) for both professors and students necessary to make the best use of online teaching, including exams.

Online education was rated as more productive than the standard one due to the absence of the use of public/private transportation (59.47\%).

Having the freedom of movement means perceiving greater comfort $(60.46 \%)$, but this did not imply greater effectiveness in teaching; indeed, only $37 \%$ agree. Just as the possibility of better organizing the workstation affected comfort (70\%) and only 56\% agreed that it could affect the effectiveness of learning. The professors also agreed that having the break during a lesson was adequate in terms of comfort $(69.77 \%)$ and student learning $(76.74 \%)$.

\subsubsection{Postures}

The professors also agreed that the configurability of the chair is important for comfort (84.09\%). The

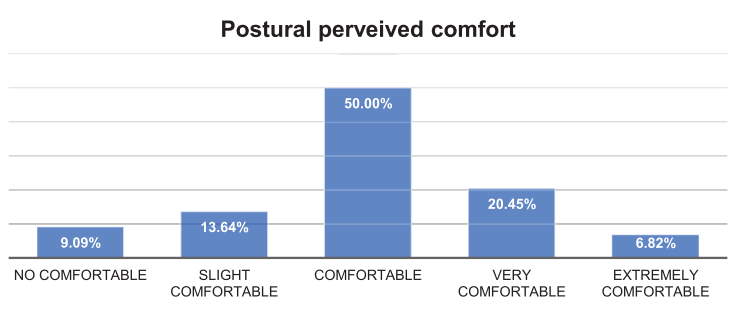

Fig. 17. Postural perceived comfort for professors.

elements that, according to them, must be focused, due to their direct influence on the postural comfort, are lumbar support (70.45\%), height adjustment $(65.91 \%)$, armrests $(61.36 \%)$, backrest $(56.82 \%)$ and the possibility of tilting (oscillating movement of the backrest, $47.73 \%$ ). The percentages are slightly different from those of the students probably because the perception of comfort varies with age (the more is old, the less is the perceived comfort).

Since also for professors, with the advent of the coronavirus, the level of a sedentary lifestyle increased $(84.09 \%$ ), postural issues (pain or MSD) can arise after two hours of lessons $(68.18 \%)$. Indeed, professors that remained seated during online teaching felt the need to stretch their legs during breaks $(61.36 \%)$. Indeed, $61.36 \%$ of them preferred to take different postures but remain in the same position during the lesson.

About $50 \%$ of professors declared to perceive a comfortable level of postural comfort (Fig. 17). The reason could be linked to the time spent on eLearning: since the time spent for online teaching is less than for students, the level of postural comfort could be generally higher despite the higher age.

\subsubsection{Visual comfort}

Being in front of the PC can lead to visual fatigue; the actions most performed by professors to improve visual wellbeing were the adjustment of the brightness of the PC $(54.55 \%)$, of the inclination of the monitor $(45.45 \%)$ and variation of posture (43.18\%).

\subsection{4. eLearning platform}

The most used type of connection is Wi-Fi $(65.91 \%)$ which for professors had a lower frequency of line problems in a week (rarely $40.91 \%$ ) compared to students (often 90\%) perhaps because the time spent on online teaching is less for professors.

\subsubsection{Devices}

The device most used during online teaching was the PC (74.07\%), and half of the professors used only 


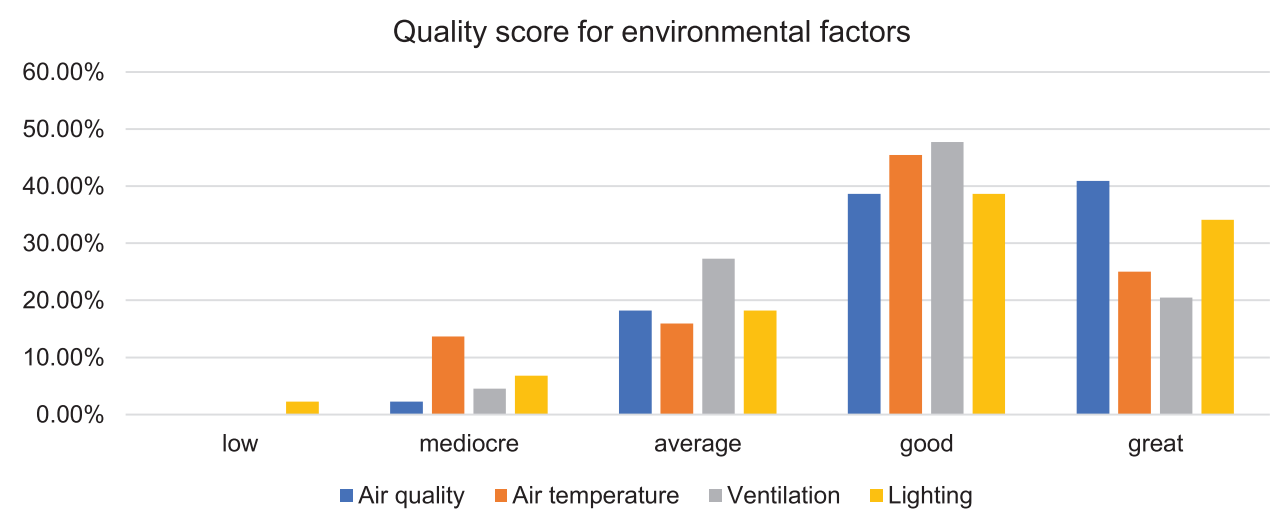

Fig. 18. Quality score of environmental parameters at home.
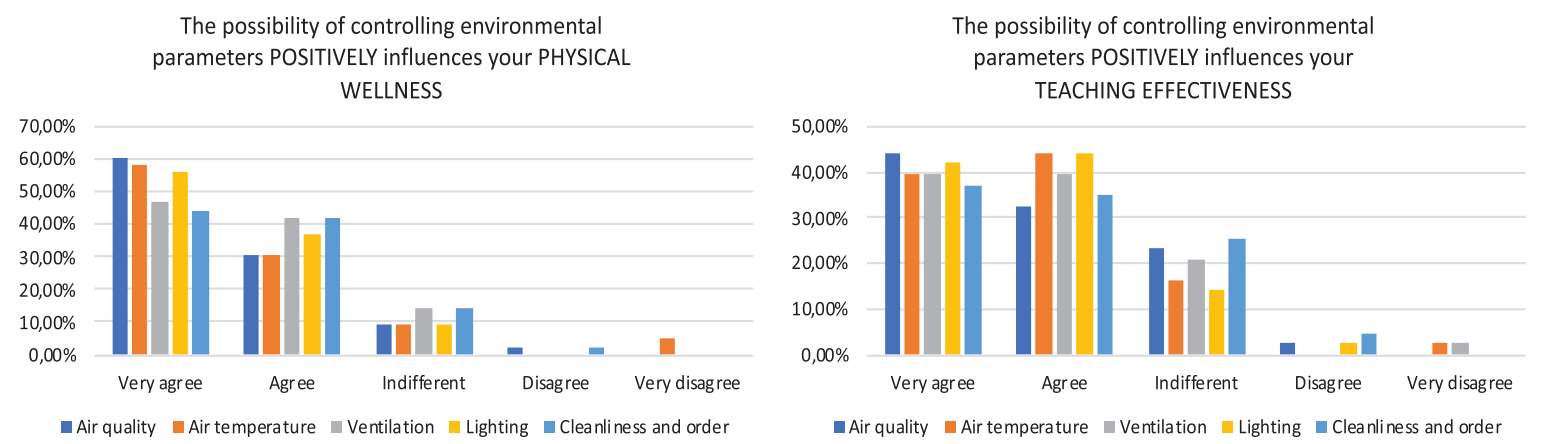

Fig. 19. Influence of controlling environmental parameters on physical wellness and teaching effectiveness.

one device $(52.27 \%)$ while the other half used multiple devices simultaneously (47.73\%). $91 \%$ used the PC exclusively, without sharing with other family members. Unlike students, most professors usually did not use the headphones, but directly the speakers of the device $(61.36 \%)$. Per $70.45 \%$ of the professors, performance limits (hardware) negatively influenced psychological stress. The large size of the screen positively affected postural comfort $(86.37 \%)$ and can also positively influence the effectiveness of teaching (78.55\%).

\subsubsection{Environmental parameters}

A quality score was asked for the following environmental factors, as shown in Fig. 18. All the environmental factors (air quality, air temperature, ventilation and lighting) scored higher values in good and great quality score (points 4 and 5 on the scale, respectively).

As far as the possibility of controlling environmental parameters since professors were at home, most of them agreed that had a positive influence on physical wellness and on teaching effectiveness, as shown in Fig. 19.

\subsubsection{Professors feedback on students}

Some professors agreed (25\%) that with online teaching lead to greater ease of learning; according to them, they have noticed greater student involvement $(23.81 \%)$ and greater visual focus $(14.29 \%)$. Those who disagreed $(43.18 \%)$ noticed an increase in students' distraction (28.57\%), a lack of interaction (14.29\%) and alienation of students $(19.05 \%)$. According to the professors, the limitation of access to the laboratories highly influenced the learning effectiveness of the students (58.12\%) as some subjects were difficult to render the concept only through online teaching. In addition, professors believed that group activity has changed negatively $(67.44 \%)$.

\subsection{Clusters and factors interdependencies}

Analysing the survey results, some relevant factors have emerged. These factors have importance both in the process of teaching/learning and in the process of formation of comfort/discomfort perception and, consequently, of personal wellbeing. Table 5 shows the summary of elements or parameters that influ- 
Table 5

Summary of parameters that influences general human comfort, wellbeing and learning effectiveness

\begin{tabular}{|c|c|c|c|}
\hline Parameters & Comfort/wellbeing & Learning effectiveness & Professors \\
\hline Preferred workstation & $\begin{array}{l}83,34 \% \text { of students chose the "desk" } \\
\text { as the best compromise for postural } \\
\text { comfort and learning effectiveness }\end{array}$ & & $\begin{array}{l}85,11 \% \text { of professors prefer to } \\
\text { conduct online lessons seated }\end{array}$ \\
\hline Chair configurability & $\begin{array}{l}88,21 \% \text { of students agree that the } \\
\text { chair configurability influences } \\
\text { postural comfort }\end{array}$ & & $\begin{array}{l}84,09 \% \text { of professors agree that } \\
\text { the chair configurability } \\
\text { influences postural comfort }\end{array}$ \\
\hline Influence of clothing & & $\begin{array}{l}52,09 \% \text { of students stated that } \\
\text { clothing has a relevant influence } \\
\text { on learning effectiveness }\end{array}$ & $\begin{array}{l}40,92 \% \text { of professors stated } \\
\text { that clothing has a relevant } \\
\text { influence on teaching effectiveness }\end{array}$ \\
\hline $\begin{array}{l}\text { The negative influence of } \\
\text { surfing on the web }\end{array}$ & & $\begin{array}{l}41,77 \% \text { of students disagree about } \\
\text { the negative influence of surfing on } \\
\text { Web during lessons on } \\
\text { learning effectiveness }\end{array}$ & \\
\hline $\begin{array}{l}\text { The negative influence } \\
\text { due to bad connection }\end{array}$ & & $\begin{array}{l}80,11 \% \text { of students agree that bad } \\
\text { connections influence } \\
\text { learning effectiveness negatively }\end{array}$ & $\begin{array}{l}63,64 \% \text { of professors agree that } \\
\text { bad connections influence } \\
\text { teaching effectiveness negatively }\end{array}$ \\
\hline $\begin{array}{l}\text { Negative influence of } \\
\text { spending hours on } \\
\text { online lessons }\end{array}$ & & $\begin{array}{l}64,48 \% \text { of students agree that } \\
\text { spending many hours on online } \\
\text { lessons influence learning } \\
\text { effectiveness negatively }\end{array}$ & $\begin{array}{l}59,09 \% \text { of professors agree that } \\
\text { spending many hours on online } \\
\text { lessons influence teaching } \\
\text { effectiveness negatively }\end{array}$ \\
\hline $\begin{array}{l}\text { Taking notes is better } \\
\text { during online lessons }\end{array}$ & $\begin{array}{l}62,65 \% \text { of students agree that taking } \\
\text { notes during online lessons is } \\
\text { better in terms of postural comfort }\end{array}$ & $\begin{array}{l}40,40 \% \text { of students agree } \\
\text { ( } 31,55 \% \text { is indifferent) that taking } \\
\text { notes during online lessons is } \\
\text { better in terms of learning effectiveness }\end{array}$ & \\
\hline $\begin{array}{l}\text { Computer performance } \\
\text { hardware limits }\end{array}$ & & $\begin{array}{l}50,77 \% \text { of students agree }(29,88 \\
\text { is indifferent) that computer } \\
\text { performance hardware affects } \\
\text { learning effectiveness negatively }\end{array}$ & $\begin{array}{l}59,09 \% \text { of professors agree } \\
\text { ( } 22,73 \% \text { is indifferent) that } \\
\text { computer performance hardware } \\
\text { affects teaching effectiveness negatively }\end{array}$ \\
\hline Screen size & $\begin{array}{l}65,70 \% \text { of students agree that the } \\
\text { screen size influences } \\
\text { postural comfort positively }\end{array}$ & $\begin{array}{l}78,81 \% \text { of students agree that } \\
\text { the screen size influence learning } \\
\text { effectiveness positively }\end{array}$ & $\begin{array}{l}\text { More than } 80 \% \text { of professors } \\
\text { agree that screen size influence } \\
\text { postural comfort and teaching } \\
\text { effectiveness positively }\end{array}$ \\
\hline $\begin{array}{l}\text { The possibility of } \\
\text { controlling environmental } \\
\text { parameters (air, temperature, } \\
\text { ventilation, illumination) }\end{array}$ & $\begin{array}{l}\text { More than } 50 \% \text { of students agree } \\
\text { that the possibility of regulating } \\
\text { environmental parameters } \\
\text { influence wellbeing positively }\end{array}$ & $\begin{array}{l}\text { More than } 50 \% \text { of students agree } \\
\text { that the possibility of regulating } \\
\text { environmental parameters } \\
\text { influence learning } \\
\text { effectiveness positively }\end{array}$ & $\begin{array}{l}\text { More than } 80 \% \text { of professors agree } \\
\text { that the possibility of regulating } \\
\text { environmental parameters } \\
\text { influence wellbeing and teaching } \\
\text { effectiveness positively }\end{array}$ \\
\hline Cleanliness and order & $\begin{array}{l}73,17 \% \text { of students agree that } \\
\text { cleanliness and order influence } \\
\text { wellbeing positively }\end{array}$ & $\begin{array}{l}66 \% \text { of students agree that } \\
\text { cleanliness and order influence } \\
\text { learning effectiveness positively }\end{array}$ & $\begin{array}{l}\text { More } 70 \% \text { of professors that } \\
\text { cleanliness and order influence } \\
\text { wellbeing and teaching } \\
\text { effectiveness positively }\end{array}$ \\
\hline
\end{tabular}


Table 5

Continued

\begin{tabular}{|c|c|c|c|}
\hline Parameters & Comfort/wellbeing & Learning effectiveness & Professors \\
\hline Noises (indoor, outdoor) & & $\begin{array}{l}\text { More than } 40 \% \text { of students declare } \\
\text { that noises affect learning } \\
\text { effectiveness negatively }\end{array}$ & $\begin{array}{l}\text { About } 50 \% \text { of professors that } \\
\text { noises affect teaching effectiveness } \\
\text { negatively, in particular internal } \\
\text { noises related to the presence } \\
\text { of family members }\end{array}$ \\
\hline $\begin{array}{l}\text { Visual contact with } \\
\text { other students }\end{array}$ & & $\begin{array}{l}50 \% \text { of students declare that visual } \\
\text { contact with other students } \\
\text { affects learning effectiveness a bit }\end{array}$ & $\begin{array}{l}65,12 \% \text { of professors declare } \\
\text { that the absence of visual } \\
\text { contact with students influence } \\
\text { teaching effectiveness negatively }\end{array}$ \\
\hline $\begin{array}{l}\text { Visual contact } \\
\text { with professors }\end{array}$ & & $\begin{array}{l}78,05 \% \text { of students declare that } \\
\text { visual contact with professors } \\
\text { affect learning effectiveness a lot }\end{array}$ & \\
\hline Breaks & $\begin{array}{l}\text { More than } 70 \% \text { of students } \\
\text { declare breaks within and } \\
\text { between lessons are } \\
\text { important for wellbeing }\end{array}$ & $\begin{array}{l}\text { More than } 60 \% \text { of students declare } \\
\text { breaks within and between lessons } \\
\text { are important for learning effectiveness }\end{array}$ & $\begin{array}{l}\text { More than } 60 \% \text { of professors } \\
\text { declare breaks are important for } \\
\text { both postural comfort and } \\
\text { learning/teaching effectiveness }\end{array}$ \\
\hline $\begin{array}{l}\text { The absence of } \\
\text { solution of continuity }\end{array}$ & $\begin{array}{l}61,74 \% \text { of students declare } \\
\text { the absence of solution of } \\
\text { continuity affects wellbeing a lot }\end{array}$ & $\begin{array}{l}56,86 \% \text { of students declare the } \\
\text { absence of solution of continuity } \\
\text { affects learning effectiveness a lot }\end{array}$ & \\
\hline Free movements & $\begin{array}{l}73,32 \% \text { of students declare that } \\
\text { being able to perform any } \\
\text { movements influences comfort a lot }\end{array}$ & $\begin{array}{l}50,15 \% \text { of students declare that } \\
\text { being able to perform any movements } \\
\text { influences learning effectiveness a lot }\end{array}$ & $\begin{array}{l}\text { More than } 40 \% \text { of professors } \\
\text { declare that feeling free to perform } \\
\text { any movement influence positively } \\
\text { both postural comfort and } \\
\text { teaching effectiveness }\end{array}$ \\
\hline Workstation organisation & $\begin{array}{l}79,27 \% \text { of students declare that } \\
\text { being able to organize their } \\
\text { workstation influence } \\
\text { postural comfort a lot }\end{array}$ & $\begin{array}{l}62,8 \% \text { of students declare that being } \\
\text { able to organize their workstation } \\
\text { influence learning effectiveness a lot }\end{array}$ & $\begin{array}{l}\text { More than } 50 \% \text { of professors } \\
\text { declare that being able to organize their } \\
\text { workstation influence a lot both } \\
\text { postural comfort and teaching effectiveness }\end{array}$ \\
\hline Free consumption & $\begin{array}{l}47,56 \% \text { of students declare that } \\
\text { being able to have free } \\
\text { consumption during online } \\
\text { lessons influence wellbeing a lot }\end{array}$ & $\begin{array}{l}\text { About } 30 \% \text { of students declare that } \\
\text { being able to have free consumption } \\
\text { during online lessons influence } \\
\text { learning effectiveness a lot }\end{array}$ & \\
\hline
\end{tabular}




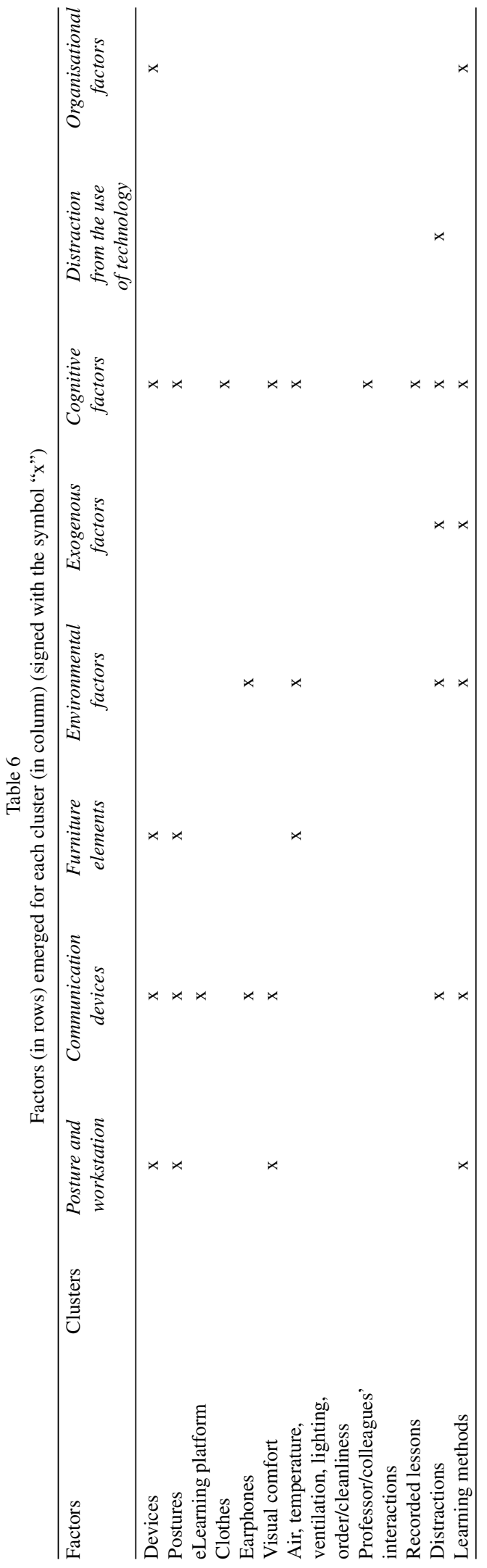

ence general human comfort, wellbeing and learning effectiveness due to the new situation. Table 5 compares also the differences between students and professors, showing some similarities between the two groups.

The need to focus on a limited set of factors is due to the realistic possibility to create a guideline for improving wellbeing while improving the effectiveness of the learning process at the same time. Table 6 shows the factors inside each cluster. The symbol " $x$ " highlights the presence of a factor in a cluster (even more than one), whose influence has been evaluated through calculated frequencies. As results, for each cluster, some factors have been highlighted as the most important to be more deeply investigated.

Table 6 shows how the cognitive factors cannot be neglected during the eLearning process, and devices', postures', distraction's, and visual comfort related factors are essential and need to be investigated through further experiments; it will become the working platform for future investigation about the dependencies and the correlation among factors and the identification of the product/interaction/ environmental characteristics on which to act in order to improve and optimise the home-working place.

\section{Conclusions}

The health emergency COVID-19 forced students and professors to change, suddenly and radically, their way of learning and teaching. The traditional "in presence" lessons were converted into online lessons. The current scenario has not previous similar situations, and it was something new at the very early stages in the pandemic. The new eLearning approach implied several changes that impacted, positively or negatively, on the teaching/learning effectiveness and the wellbeing of all the people involved. Thus, the research question was: Which are the factors that affected both teaching/learning effectiveness and general human comfort and wellbeing, after the sudden transition from classrooms to eLearning platform due to COVID-19 in Italy, and how?

The Naddeo et al. comfort model [60] was used as a milestone to generate the clusters among which identify and classify the factors that could affect both teaching/learning effectiveness and general human comfort and wellbeing. A workshop-like brainstorming among experts and users (professors and $\mathrm{PhD} / \mathrm{MD}$ students) was performed to create and organize a sur- 
vey in which each cluster of interest has been deeply investigated. The identified factors inside the clusters were investigated by two questionnaires (one for teachers and one for students) that were spread out among Italian universities in order to evaluate which of them really affect the new eLearning situation and how, and, consequently, to respond to the research question. The analysis of the 700 filled in questionnaires allowed us to evaluate how factors qualitatively impacted (positively or negatively) on the teaching/learning effectiveness and the wellbeing of all involved people. The impossibility to interact with colleagues, the necessity to adapt our homes to make them suitable for smart-working (teaching) or attending eLearning courses, the necessity to use several devices are an example of the many aspects that emerged from the survey.

As a main result, the most important factors that need to be deeply investigated have been highlighted in Table 6, that is useful to identify the most affecting factor immediately and to understand how (positively or negatively) the factor influence learning/teaching effectiveness and comfort/discomfort. Furthermore, this table allows fulfilling the need to focus on a limited set of factors to be considered for the creation of a guideline for improving wellbeing while improving the effectiveness of the learning process at the same time. Finally, Table 6 allows understanding the interdependencies among factors and highlights both the complexity of the overall problem and the way to face it with a multi-factorial [76] or an axiomatic [87] approach.

\subsection{Study limitations}

The survey, with about 130 questions and 700 interviews (students and teachers) can be considered sufficient to carry out an in-depth study of the phenomenon analysed. However, the work has some limitations to be acknowledged.

First of all, the study involved only Italian Universities. So, it would be interesting to understand if, in other countries, issues and new eLearning methods were almost similar. Moreover, it is not possible to exclude the hypothesis that some other factors have not been considered during the workshop. Indeed, during the workshop, the students were asked to insert the identified factors (first independently and then in the group) in the eight identified clusters. This step could have created information leakage: factors that at first glance did not fit into any of the clusters considered may have been eliminated. Having been pro- vided with the 8 clusters, the students concentrated on those, and some factors have probably been forgotten.

Most data are subjective or based to respondents' perceptions, and only a few data can be objectively measured (such as personal information, lessons duration, weekly scheduling, the number of devices, etc.). However, this work aimed to investigate which factors influence the eLearning during the lockdown. Moreover, the internal consistency analysis of the data had not been carried out.

Finally, since some questions were without a scale and data were from questionnaires/survey, that represented a not controlled condition and only based on respondents' perceptions, correlations had not been calculated. However, critical factors will be evaluated in a controlled test (future work) that will involve the outcomes of this paper.

\subsection{Future developments}

The survey results, considering more than 10 factors, provide a comprehensive analysis of the influences in wellbeing and learning effectiveness during the sudden transition into eLearning due to the COVID-19 lockdown.

At this point, the question that arises is: which are the most significant factors, among those considered? Can this data be used to provide guidelines for improving comfort and learning?

The next step will be to carry out a statistical analysis of the data: through the response rate, the mean and the variance the most significant factors can be identified.

The authors aim to evaluate, again, these identified factors with a more limited sample through controlled experiments and drawing up an ad-hoc questionnaire to analyse in detail the learning effectiveness and comfort in this situation. The next work wants to define the guidelines for the ergonomic design of a workspace in online learning.

\section{Acknowledgments}

Authors want to thank all people involved in the workshop and all students of the last year of MD in Mechanical Engineering and MD in Industrial Engineering that attended the courses in the second semester of the 2019-2020 Academic Year at the University of Salerno (Italy). A special thanks is given to Eng. Liliana di Brigida, Prof. Nicola Cap- 
petti and $\mathrm{PhD}$ student Carlotta Fontana for their help and advice during the workshop.

\section{Conflict of interest}

None to report.

\section{Supplementary material}

The questionnaires for students and professors are available from https://dx.doi.org/10.3233/WOR203358.

\section{References}

[1] Huang C, Wang Y, Li X, Ren L, Zhao J, Hu Y, et al. Clinical features of patients infected with 2019 novel coronavirus in Wuhan, China. Lancet. 2020;395.

[2] Murphy MPA. COVID-19 and emergency eLearning: Consequences of the securitization of higher education for post-pandemic pedagogy. Contemp Secur Policy [Internet]. 2020;41(3):492-505. Available from: https://doi. org/10.1080/13523260.2020.1761749

[3] World Health Organization. Coronavirus disease (COVID19) pandemic. 2020.

[4] Mulla Z, Osland-Paton V, Rodriguez M, Vazquez E, Plavsic S. Novel coronavirus, novel faculty development programs: rapid transition to eLearning during the pandemic. J Perinat Med. 2020;48.

[5] Girik Allo M. Is the online learning good in the midst of Covid-19 Pandemic? The case of EFL learners. 2020;10:110.

[6] La Repubblica. eLearning in Italy [Internet]. 2020. Available from: https://www.repubblica.it/scuola/2020/03/13/ news/coronavirus_la_didattica_a_distanza_decolla_lezioni_ online_per_9_studenti_su_10-251205013/

[7] Bright C, Lindsay E, Lowe D, Murray S, Liu D. Factors that impact learning outcomes in Remote Laboratories. 2008 Jan $1 ;$

[8] Iulm. Online teaching: the testimonials of students and teachers [Internet]. 2020. Available from: https://www.iulm. it/it/news-ed-eventi/news/didattica-online-testimonianzedocenti-studenti

[9] Reyes-Chua E, Sibbaluca BG, Miranda RD, Palmario GB, Moreno RP, Solon JPT. The status of the implementation of the e-learning classroom in selected higher education institutions in region IV - A amidst the covid-19 crisis. J Crit Rev [Internet]. 2020;7(11):253-8. Available from: https://www.scopus.com/inward/record.uri?eid=2-s2.0$85086226733 \&$ doi $=10.31838 \% 2$ Fjcr.07.11.41\&partnerID= $40 \& \mathrm{md} 5=4 \mathrm{~b} 217 \mathrm{~b} 193 \mathrm{~d} 21 \mathrm{ae} 77 \mathrm{c} 16 \mathrm{cc} 0 \mathrm{~d} 3 \mathrm{~d} 4502 \mathrm{edf}$

[10] Sun A, Chen X. Online Education and Its Effective Practice: A Research Review. J Inf Technol Educ Res. 2016;15:15790.

[11] Kirkwood A, Price L. Technology-enhanced learning and teaching in higher education: what is 'enhanced' and how do we know? A critical literature review. Learn Media Tech- nol [Internet]. 2014;39(1):6-36. Available from: https:// doi.org/10.1080/17439884.2013.770404

[12] Magalhães P, Ferreira D, Cunha J, Rosário P. Online vs traditional homework: A systematic review on the benefits to students' performance. Comput Educ [Internet]. $2020 \mathrm{Jul}$ 1 [cited 2020 Apr 4];152:103869. Available from: https:// www.sciencedirect.com/science/article/pii/S03601315 20300695

[13] Moore MG. Theory of transactional distance. In: Keegan D, editor. Theoretical Principles of Distance Education. Routledge; 1997. pp. 22-38.

[14] Eldeeb R. Students' Perceptions to e- Learning. Int J Res Method Educ. 2014;

[15] Popovici A, Mironov C. Students' Perception on Using eLearning Technologies. Procedia - Soc Behav Sci. 2015; 180:1514-9.

[16] Vitoria L, Mislinawati M, Nurmasyitah N. Students' perceptions on the implementation of e-learning: Helpful or unhelpful? J Phys Conf Ser. 2018;1088:12058.

[17] Pappas C. Top 20 eLearning Statistics For 2019 [Internet]. 2019. Available from: https://elearningindustry.com/topelearning-statistics-2019

[18] Gutierrez K. Facts and Stats That Reveal The Power Of eLearning [Internet]. 2016. Available from: https://www. shiftelearning.com/blog/bid/301248/15-facts-and-statsthat-reveal-the-power-of-elearning

[19] Robertson M, Vink P. Examining new ways of office work between the Netherlands and the USA. Work. 2012; 41:5086-90.

[20] Kurland N, Cooper C. Manager Control and Employee Isolation in Telecommuting Environments. J High Technol Manag Res. 2002;13:107-26.

[21] Gajendran RS, Harrison DA. The good, the bad, and the unknown about telecommuting: Meta-analysis of psychological mediators and individual consequences. Vol. 92, Journal of Applied Psychology. Gajendran, Ravi S.: Department of Management and Organization, Pennsylvania State University, 426 B Business Building, University Park, PA, US, 16802,rsg183@psu.edu: American Psychological Association; 2007. pp. 1524-41.

[22] Benson R. Helping Pupils Overcome Homework Distractions. Clear House A J Educ Strateg Issues Ideas [Internet]. 1988;61(8):370-2. Available from: https://doi.org/10. 1080/00098655.1988.10113974

[23] Xu J, Corno L. Case studies of families doing third-grade homework. Teach Coll Rec [Internet]. 1998;100(2):402-36. Available from: https://www.scopus.com/inward/record. uri?eid=2-s2.0-0032349481\&partnerID=40\&md5=babb0c bbd8557b121f0c4c1b002c4db7

[24] Cooper H, Lindsay JJ, Nye B. Homework in the Home: How Student, Family, and Parenting-Style Differences Relate to the Homework Process. Contemp Educ Psychol [Internet]. 2000;25(4):464-87. Available from: http://www. sciencedirect.com/science/article/pii/S0361476X99910366

[25] Zannin PHT, Marcon CR. Objective and subjective evaluation of the acoustic comfort in classrooms. Appl Ergon [Internet]. 2007;38(5):675-80. Available from: http://www. sciencedirect.com/science/article/pii/S0003687006001566

[26] Braat-Eggen PE, van Heijst A, Hornikx M, Kohlrausch A. Noise disturbance in open-plan study environments: a field study on noise sources, student tasks and room acoustic parameters. Ergonomics [Internet]. 2017;60(9):1297314. Available from: https://doi.org/10.1080/00140139. 2017.1306631 
[27] Barlow S, Fiala D. Occupant comfort in UK offices-How adaptive comfort theories might influence future low energy office refurbishment strategies. Energy Build [Internet]. 2007;39(7):837-46. Available from: http://www.scien cedirect.com/science/article/pii/S0378778807000394

[28] Xu J. Investigating factors that influence conventional distraction and tech-related distraction in math homework. Comput Educ [Internet]. 2015;81:304-14. Available from: http://www.sciencedirect.com/science/article/pii/S036013 1514002449

[29] Calderwood C, Ackerman PL, Conklin EM. What else do college students "do" while studying? An investigation of multitasking. Comput Educ [Internet]. 2014;75:1929. Available from: http://www.sciencedirect.com/science/ article/pii/S0360131514000384

[30] Dietz S, Henrich C. Texting as a distraction to learning in college students. Comput Human Behav [Internet]. 2014;36:163-7. Available from: http://www.sciencedirect. com/science/article/pii/S0747563214001678

[31] Sana F, Weston T, Cepeda NJ. Laptop multitasking hinders classroom learning for both users and nearby peers. Comput Educ [Internet]. 2013;62:24-31. Available from: https:// www.scopus.com/inward/record.uri?eid=2-s2.0-8486911 $7802 \&$ doi $=10.1016 \% 2 \mathrm{Fj}$. compedu. $2012.10 .003 \&$ partner ID $=40 \& m d 5=6 a c c d 390 c 2 f 00 b 6 f 4280237 d 4130324 a$

[32] Xu J. Models of secondary school students' Interest in homework: A multilevel analysis. Am Educ Res J [Internet]. 2008;45(4):1180-205. Available from: https://www. scopus.com/inward/record.uri?eid=2-s2.0-68049148113\& doi $=10.3102 \% 2 F 0002831208323276 \&$ partnerID $=40 \&$ md5 $=63412 \mathrm{~d} 15 \mathrm{e} 709 \mathrm{dc} 550 \mathrm{a} 15 \mathrm{~d} 90 \mathrm{e} 86472 \mathrm{eca}$

[33] Wallis C. The multitasking generation. Time [Internet]. 2006;167(13):48-55. Available from: https://www.scopus. com/inward/record.uri?eid=2-s2.0-33646114753\&partner ID $=40 \& \mathrm{md} 5=\mathrm{dd} 105 \mathrm{c} 63 \mathrm{f} 85 \mathrm{fa} 4 \mathrm{f} 356799 \mathrm{e} 1 \mathrm{de} 21940 \mathrm{fc}$

[34] David P, Kim J-H, Brickman JS, Ran W, Curtis CM. Mobile phone distraction while studying. New Media Soc [Internet]. 2015;17(10):1661-79. Available from: https:// doi.org/10.1177/1461444814531692

[35] Fiorillo I, Anzisi FJ, Carbone A, Califano R, Naddeo A. A comfort evaluation tool for sitting postures: the case of Library chairs. In: WORK [Internet]. 2019. Available from: http://hdl.handle.net/11386/4738023

[36] Fasulo L, Naddeo A, Cappetti N. A study of classroom seat (dis)comfort: Relationships between body movements, center of pressure on the seat, and lower limbs' sensations. Appl Ergon. 2019;74:233-40.

[37] Naddeo A, Califano R, Vink P. The effect of posture, pressure and load distribution on (dis)comfort perceived by students seated on school chairs. Int J Interact Des Manuf. 2018;

[38] Naddeo A, Fasulo L, Vallone M. Ergonomic analysis and comfort driven redesign of student classroom combo desks at university of Salerno (Italy). J Ind Des Eng Graph. 2015; 10:33-44.

[39] M. Cecco, G. Cunzo, N Napolitano, E. Rega, I. Fiorillo RCAN. School combo-desk comfort assessment: a method for weighing postural factors that affect the overall perceived comfort while performing different activities. In: Peter Vink, Alessandro Naddeo, Susanne Frohriep, Neil M, editor. The Second International Conference on Comfort (ICC2019). Delft; 2019.

[40] HIRA DS. An ergonomic appraisal of educational desks. Ergonomics [Internet]. 1980;23(3):213-21. Available from: https://doi.org/10.1080/00140138008924735
[41] Castellucci HI, Arezes PM, Molenbroek JFM. Equations for defining the mismatch between students and school furniture: A systematic review. Int J Ind Ergon [Internet]. 2015 Jul 1 [cited 2019 Jan 20];48:117-26. Available from: https:// www.sciencedirect.com/science/article/abs/pii/S0169814 115000670

[42] Parcells C, Stommel M, Hubbard RP. Mismatch of classroom furniture and student body dimensions: Empirical findings and health implications. J Adolesc Heal. 1999; 24(4):265-73.

[43] $\mathrm{Ng}$ PK, Jee K, Yee Lim S. Development of Ergonomics Guidelines for Improved Sitting Postures in the Classroom among Malaysian University Students. Vol. 13, American Journal of Applied Sciences. 2016. pp. 907-12.

[44] Castellucci HI, Arezes PM, Viviani CA. Mismatch between classroom furniture and anthropometric measures in Chilean schools. Appl Ergon. 2010;41(4):563-8.

[45] Dianat I, Karimi MA, Asl Hashemi A, Bahrampour S. Classroom furniture and anthropometric characteristics of Iranian high school students: Proposed dimensions based on anthropometric data. Appl Ergon [Internet]. 2013;44(1): 101-8. Available from: http://www.sciencedirect.com/sci ence/article/pii/S0003687012000671

[46] Koskelo R, Vuorikari K, Hänninen O. Sitting and standing postures are corrected by adjustable furniture with lowered muscle tension in high-school students. Ergonomics. 2007;50(10):1643-56.

[47] Mohamed Thariq MG, Munasinghe HP, Abeysekara JD. Designing chairs with mounted desktop for university students: Ergonomics and comfort. Int J Ind Ergon. 2010; 40(1):8-18

[48] Honan M. Mobile work: Ergonomics in a rapidly changing work environment. Work. 2015;52(2):289-301.

[49] Hamberg-van Reenen HH, van der Beek AJ, Blatter BM, van der Grinten MP, van Mechelen W, Bongers PM. Does musculoskeletal discomfort at work predict future musculoskeletal pain? Ergonomics. 2008;51(5):637-48.

[50] Alessandro N, Sandro M. Postural comfort inside a car: Development of an innovative model to evaluate the discomfort level. SAE Int J Passeng Cars - Mech Syst. 2009;2(1).

[51] Sanjog J, Patel T, Chowdhury A, Karmakar S. Musculosk eletal ailments in Indian injection-molded plastic furniture manufacturing shop-floor: Mediating role of work shift duration. Int J Ind Ergon [Internet]. 2015 Jul 1 [cited 2019 Jan 20];48:89-98. Available from: https://www.scien cedirect.com/science/article/abs/pii/S0169814115000554

[52] Michael A, Heracleous C. Assessment of natural lighting performance and visual comfort of educational architecture in Southern Europe: The case of typical educational school premises in Cyprus. Energy Build [Internet]. 2017;140:44357. Available from: http://www.sciencedirect.com/science/ article/pii/S037877881632076X

[53] Cajochen C, Freyburger M, Basishvili T, Garbazza C, Rudzik F, Renz C, et al. Effect of daylight LED on visual comfort, melatonin, mood, waking performance and sleep. Light Res Technol [Internet]. 2019;51(7):1044-62. Available from: https://doi.org/10.1177/1477153519828419

[54] Md Tamrin S, Sia CC, Ng YG, Karmegan K. Effects of Light's Colour Temperatures on Visual Comfort Level, Task Performances, and Alertness among Students. Am J Public Heal Res. 2013;1:159-65.

[55] Korsavi S, Zomorodian M, Tahsildoost M. Visual comfort assessment of daylit and sunlit areas: A longitudinal Field survey in Classrooms in Kashan, Iran. Energy Build. 2016;128. 
[56] Marchand GC, Nardi NM, Reynolds D, Pamoukov S. The impact of the classroom built environment on student perceptions and learning. J Environ Psychol. 2014;

[57] Higgins S, Hall E, Wall K, Woolner P, McCaughey C. The Impact of School Environments: A Literature Review. Cent Learn Teaching-School Educ Commun Lang Sci Univ Newcastle. 2005;

[58] Galinsky T, Swanson N, Sauter S, J. Hurrell J, M. Schleifer L. A field study of supplementary rest breaks for data-entry operators. Ergonomics. 2000;43:622-38.

[59] Pinto S, Fumincelli L, Mazzo A, Caldeira S, Martins JC. Comfort, well-being and quality of life: Discussion of the differences and similarities among the concepts. Porto Biomed J [Internet]. 2017;2(1). Available from: https://jour nals.lww.com/pbj/Fulltext/2017/01000/Comfort,_well_ being_and_quality_of_life_.3.aspx

[60] Naddeo A, Cappetti N, Vallone M, Califano R. New trend line of research about comfort evaluation: proposal of a framework for weighing and evaluating contributes coming from cognitive, postural and physiologic comfort perceptions. In: Vink P, editor. Advances in Social and Organizational Factors. Cracovia; 2014. pp. 503-15.

[61] Naddeo A. Towards predicting the (dis)comfort performance by modelling: methods and findings. TU Delft; 2017.

[62] Kamp I. The influence of car-seat design on its character experience. Appl Ergon [Internet]. 2012 Mar 1 [cited 2018 Dec 7];43(2):329-35. Available from: https://www.science direct.com/science/article/pii/S0003687011000810?via\% 3Dihub

[63] Noro K, Naruse T, Lueder R, Nao-i N, Kozawa M. Application of Zen sitting principles to microscopic surgery seating. Appl Ergon [Internet]. 2012;43(2):308-19. Available from: http://www.sciencedirect.com/science/article/pii/S0003687 011000792

[64] Cascioli V, Heusch AI, McCarthy PW. Does prolonged sitting with limited legroom affect the flexibility of a healthy subject and their perception of discomfort? Int $\mathbf{J}$ Ind Ergon [Internet]. 2011;41(5):471-80. Available from: http://www.sciencedirect.com/science/article/pii/S0169814 111000813

[65] Tourangeau R. Cognitive Aspects of Survey Measurement and Mismeasurement. Int J Public Opin Res. 2003;15.

[66] Desselle S. Construction, Implementation, and Analysis of Summated Rating Attitude Scales. Am J Pharm Educ. 2005;69.

[67] Groves R, Fowler F, Couper M, Lepkowski J, Singer E, Tourangeau R. Survey Methodology. 2004;561.

[68] Salant P, Dillman DA. How to Conduct Your Own Survey. 1994. pp. 256.

[69] Presser S, Blair J. Survey pretesting: Do different methods produce different results? Sociological Methodology. 1994;24:73-104.

[70] Rothgeb JM, Willis G, Forsyth BH. Questionnaire Pretesting Methods. Do Different Techniques and Different Organizations Produce Similar Results. In 2007.

[71] Mohamed Thariq MG, Munasinghe HP, Abeysekara JD. Designing chairs with mounted desktop for university students: Ergonomics and comfort. Int J Ind Ergon [Internet]. 2010;40(1):8-18. Available from: http://www.sciencedirect. com/science/article/pii/S0169814109001280

[72] Reenen HHH, van der Beek AJ, Blatter BM, van der Grinten MP, van Mechelen W, Bongers PM. Does musculoskeletal discomfort at work predict future musculoskeletal pain? Ergonomics [Internet]. 2008;51(5):637-48. Available from: https://doi.org/10.1080/00140130701743433
[73] Piro S, Fiorillo I, Anjani S, Smulders M, Naddeo A, Vink P. Towards comfortable communication in future vehicles. Appl Ergon [Internet]. 2019;78:210-6. Available from: http://www.sciencedirect.com/science/article/pii/S000368 7019300602

[74] Fiorillo I, Piro S, Anjani S, Smulders M, Song Y, Naddeo A, et al. Future vehicles: the effect of seat configuration on posture and quality of conversation. Ergonomics. 2019;

[75] Naddeo A, Di Brigida L, Fontana C, Montese J, Quartuccia M, Nasti M, et al. A body-shaped lumbar-sacral support for improving car-seat comfort. Work. 2019;

[76] Naddeo A, Califano R, Vallone M, Cicalese A, Coccaro $\mathrm{C}$, Marcone F, et al. The effect of spine discomfort on the overall postural (dis)comfort. Appl Ergon. 2019;74.

[77] Bouwens JMA, Fasulo L, Hiemstra-van Mastrigt $S$, Schultheis UW, Naddeo A, Vink P. Effect of in-seat exercising on comfort perception of airplane passengers. Appl Ergon. 2018;73:7-12.

[78] Wong ASW, Li Y, Zhang X. Influence of Fabric Mechanical Property on Clothing Dynamic Pressure Distribution and Pressure Comfort on Tight-Fit Sportswear. <IF01>. 2004;60(10):293-9.

[79] Scheurell DM, Spivak SM, Hollies NRS. Dynamic Surface Wetness of Fabrics in Relation to Clothing Comfort. Text Res J [Internet]. 1985;55(7):394-9. Available from: https://doi.org/10.1177/004051758505500702

[80] Kamalha E, Zeng Y, Mwasiagi JI, Kyatuheire S. The Comfort Dimension; a Review of Perception in Clothing. J Sens Stud [Internet]. 2013;28(6):423-44. Available from: https://onlinelibrary.wiley.com/doi/abs/10.1111/joss. 12070

[81] Marchand GC, Nardi NM, Reynolds D, Pamoukov S. The impact of the classroom built environment on student perceptions and learning. J Environ Psychol [Internet]. 2014;40:187-97. Available from: http://www.sciencedirect. com/science/article/pii/S0272494414000589

[82] Magalhães P, Ferreira D, Cunha J, Rosário P. Online vs traditional homework: A systematic review on the benefits to students' performance. Comput Educ [Internet]. 2020;152:103869. Available from: http://www.science direct.com/science/article/pii/S0360131520300695

[83] Reeve J, Nix G, Hamm D. Testing models of the experience of self-determination in intrinsic motivation and the conundrum of choice. Vol. 95, Journal of Educational Psychology. Reeve, Johnmarshall: Div of Psychological \& Quantitative Foundations, U Iowa, 361 Lindquist Ctr, Iowa City, IA, US, 52242, johnmarshall-reeve@uiowa.edu: American Psychological Association; 2003. pp. 375-92.

[84] Scharle A, Szabo A, Szabó A. Learner Autonomy: A Guide to Developing Learner Responsibility [Internet]. Cambridge University Press; 2000. (Cambridge Handbooks for Language Teachers). Available from: https://books.google. it/books?id=MRKiSmoe_5cC

[85] Duffy GL. Modular Kaizen. Continuous and Breakthrough Improvement. 2013. pp. 224.

[86] Miller A. The Andrew K. Miller Blog [Internet]. 2019. Available from: http://www.andrewkmiller.com/tag/pbl/

[87] Cappetti N, Naddeo A, Califano R, Vallone M. Using axiomatic design to identify the elements that affect the evaluation of comfort/discomfort perception. Vol. 487, Advances in Intelligent Systems and Computing. 2017. 